\title{
Opinion
}

\section{Participative Mindscapes}

\section{Roger Katan}

6 Rue des Bourgades, 30610 Sauve, France; roger.katan@wanadoo.fr; Tel.: +33-466-775-629

Received: 20 March 2015; Accepted: 21 October 2015; Published: 1 March 2016

\begin{abstract}
In parallel with my social activism, I introduced architecture into my kinetic art and participatory activism into my architecture. Flexibility and participation in architectural design has been a permanent feature of my practice, bringing new opportunities for self-expression in urban living. To form follows function I opposed form follows movement because it is man oriented while function is object oriented. After my 1962-1964 Mecanographs, machine-made images based on an interaction between the movement, the artist and the machine, I joined forces with Len Lye to determine what kind of positive attributes a Museum of Kinetic Art should have, defining three aspects of kinetic movement: illumination, sound, and physical movement. Vasarely and other kinetic artists put their mark on their time by promoting a form of social art, accessible to all, suggesting movement without actual movement. Walking through my medieval village can be a kinetic experience. The sense of wonder you feel at every corner compares with that of optical art. In the past decade, I moved toward a new form of participatory kinetic expression using state-of-the-art technology (plastics, LED, wireless devices). I view my kinetic work as an architectural experience and architecture as a stimulating kinetic experience.
\end{abstract}

Keywords: kinetic art; architecture; participation

\section{Introduction}

I was born in a tiny village of Morocco, in a mud house built by my grandfather, close to the Sahara desert. Very early on, I was puzzled by changes of lights combined with magic shiny dust particles in the air. I often imagined flying with them into the larger faraway civilized world I was taught about at school. Winning a competition to design my high school emblem among 700 participants, prompted me to study art and architecture. After earning a degree in Architecture from the Paris École des Beaux Arts, and the yearly Grunsfeld fellowship for a Master's degree at MIT in 1960, I worked two years in the prestigious office of Louis Kahn (1962-1963). At a time of great social upheaval, I decided to teach and spend more time providing free technical advice to the East Harlem community. This is when, as if to balance my oft-frustrating social work, I felt the need to take refuge and get involved in painting and investigate art in motion.

\section{Movement without Movement}

The fifties and sixties of the last century are known for revolutionary changes across disciplines and in general principles of quotidian living. As a young architect I became part of a new generation of community activists in the arts and architectural fields. We engaged the public in planning their communities, and explored technologies that permitted variety and adaptability of architectural alternatives. Along with my social activism, I introduced architecture into my kinetic art and participatory activism into my architecture. In this essay, I would like to draw a parallel between how kinetic and optical art moved painting and sculpture out from the golden cage of the museum into a challenging encounter with the larger public, and architectural developments of the early sixties in 
the movement of advocacy planning. Early on, I tried to capture movement through my paintings (Figure 1).

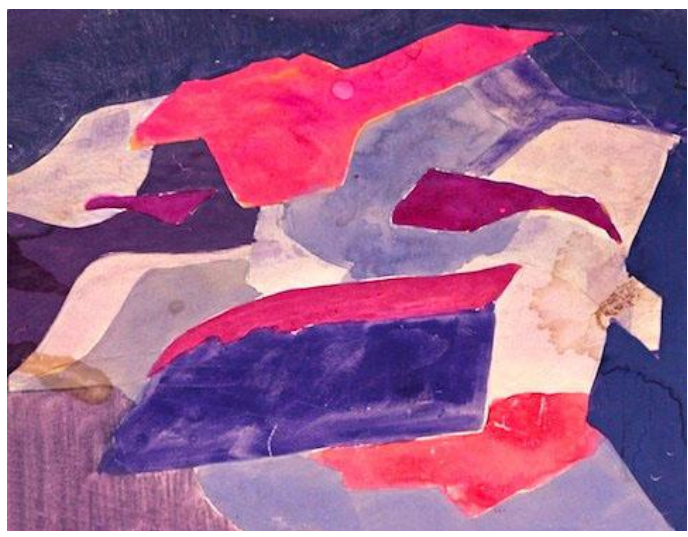

(a)

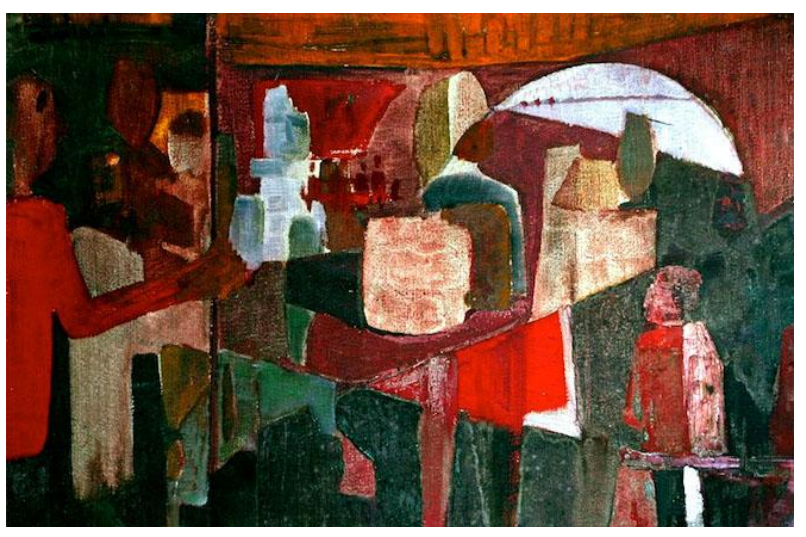

(b)

Figure 1. (a) "L'envol" $27 \mathrm{~cm} \times 21 \mathrm{~cm}, 1956$; (b) "Paris Metro by Rush Hour" $72 \mathrm{~cm} \times 48 \mathrm{~cm}, 1956$. Images are paintings by Roger Katan and are reproduced with his permission.

Victor Vasarely and other kinetic artists put their mark on their time by promoting a form of social art, accessible to all, suggesting movement without actual movement (like my own paintings above). As Lázsló Moholy-Nagy's 1922 manifesto stated: "We must therefore put in the place of the static principle of classical art the dynamic principle of universal life ... in which the material is employed as the carrier of forces ... whereby man, hitherto merely receptive in his observation of works of art, experiences a heightening of his own faculties, and becomes himself an active partner with the forces unfolding in himself" [1] (p. 290). This was one of the first promotions of participatory involvement. Vasarely was also an early promoter of this concept. I was influenced by how his playful deformed grids challenged the eye and the suggestion of movement without the actual movement. It established a new relationship between artwork and its viewer by provoking the latter's active participation. Figure 2 shows an evolution of this concept.

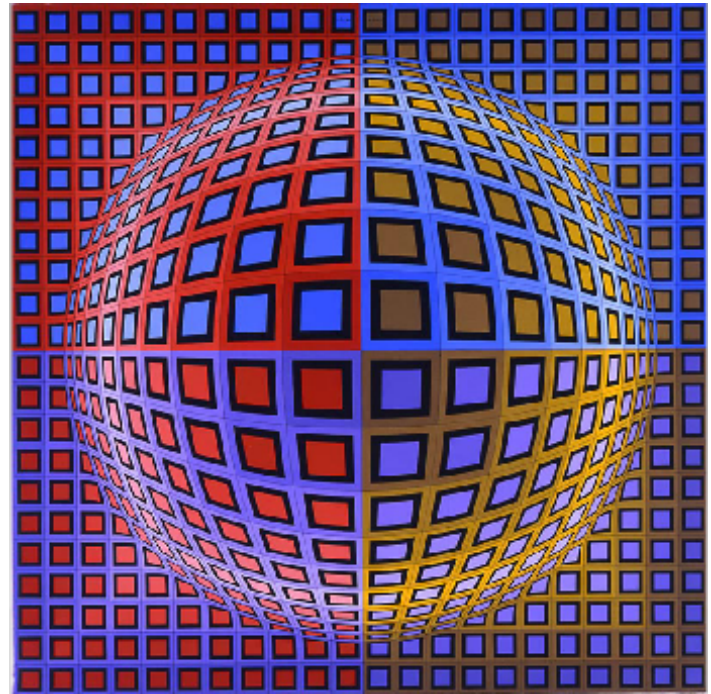

(a)

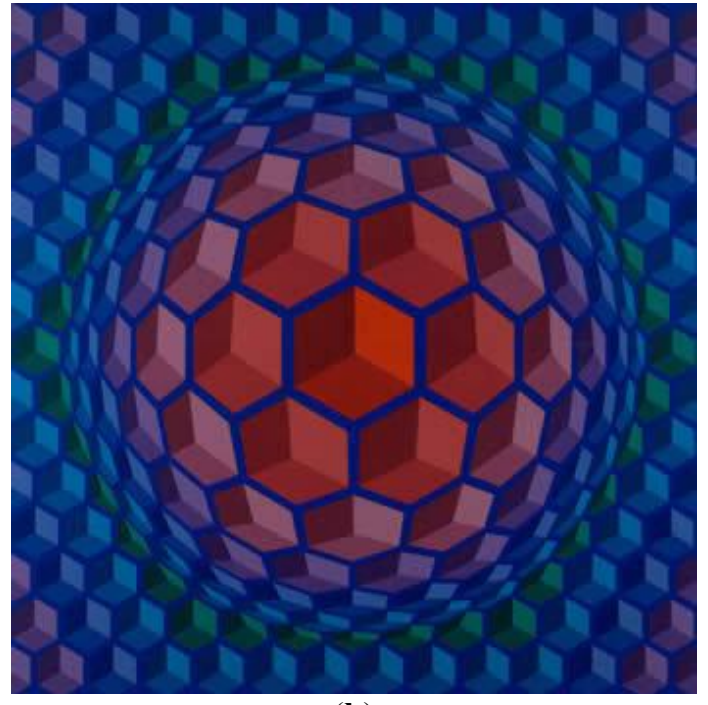

(b)

Figure 2. (a) "Vega-Szebb" $130 \mathrm{~cm} \times 130 \mathrm{~cm}$, 1974; (b) "Vega-200" $2 \mathrm{~m} \times 2 \mathrm{~m}$, 1968. Images are by Vasarely and are reproduced with permission from Michèle Vasarely. 
My professional life as an architect and artist started in Paris by the end of the 1950s, and fully developed by the mid-1960s in the United States. After receiving a fellowship to study at MIT in 1960, I worked two years in the office of Louis Kahn from 1962 to 1964 . As I indirectly experienced the social upheavals of the early 1960s (race riots in the ghettos of every major American urban center and demonstrations demanding changes in the social structure at the universities), I began to question the ambiguous and often contradictory roles of architecture and of our institutions in a society in the midst of such change. The tension I felt between the pure aesthetic vision of architectural practice, as exemplified in Louis Khan's prestigious company, and the diverse movements driven by the ideals of justice, freedom, and ethnic expression flaring up all around, was becoming untenable.

After working with Louis Kahn, my older dream of becoming the greatest architect faded away. In search of a new form of practice, I began to teach architecture to graduate and undergraduate students in New York City. By mid-1964, I moved from Philadelphia to East Harlem in New York, to work as an advocate planner and architect, while also teaching architecture at the Pratt Institute. I questioned the practice of conventional architecture, as I knew it, as simply contributing to the social unrest, whether consciously or not. How could one remain professionally passive in the midst of a major national social crisis? The disparities between the beneficiaries of a wealthy society on the one hand, and blacks and ethnic minorities, parked in slum neighborhoods or in high-rise public housing projects on the other, had become too vast to sustain. I advocated the saying of the times: "If you are not part of the solution, you are part of the problem."

Throughout the country, universities were in turmoil. Repeated demonstrations against the Vietnam War, coupled with student protests for a more social approach to architecture, led to major student strikes. Through professional publications, many universities and student organizations heard of my work. I was invited to speak in seminars across the country to help students and young professionals start their own Community Design Center.

\section{Low Cost Housing Projects Demolition: A Great Kinetic Happening}

Le Corbusier's high-rise early housing ideas, like his Plan Voisin for the center of Paris, caught the wave that spread through an agenda to rebuild Europe and the world [2]. After World War II, building industrialization was geared to house a maximum of people in a minimum of time. By the early 1990s, the Atlanta Housing Authority owned around 14,000 low cost housing units, claiming to have the highest proportion of its residents in public housing. Two decades later, that proportion has fallen all the way to zero. Atlanta has systematically torn down its traditional brick and cinder block public housing projects.

France demonstrated how to build faster, and exported worldwide its low cost technology for the low-income public housing projects (Figure 3), generating endless social problems. In Europe and in the US, thousands of low-income housing units, built in the fifties were demolished in the sixties and seventies. What a tremendous kinetic happening to see those high-rise housing structures crumble into dust!

Once heralded as the highest architectural innovation in the early sixties, the infamous Pruitt-Igoe public housing project in St. Louis, Missouri (Figure 4a) was less than 20 years old when it was demolished as a nuisance and danger zone. By 1972, after spending millions in failed attempts to cure the massive physical and social project's problems, thirty-three large structures, fifteen to twenty stories high, were razed to the ground (Figure $4 \mathrm{~b}$ ).

This St. Louis demolition, along with the previous European public housing ones, was by far the largest kinetic happening that marked a failure of modernism, which is expressed in Jean Tinguely's Destructive Art pieces (Video 1a). In making this parallel, we can say that while Tinguely's art pieces were unique statements that provoked societal questions, the housing demolitions had greater consequences: they destroyed many lives during the years of their existence. The great kinetic happening of the Pruitt-Igoe demolition into dust (one of the first and most dramatic) can be viewed in Video $1 b$. 


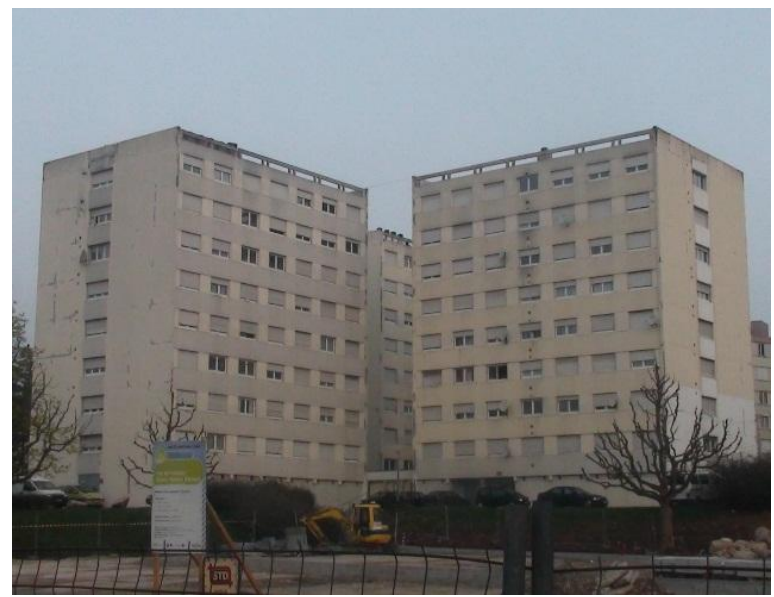

Figure 3. Typical housing of the mid-1950s and 1960s in Europe. Image courtesy of Toufik-de-planoise.

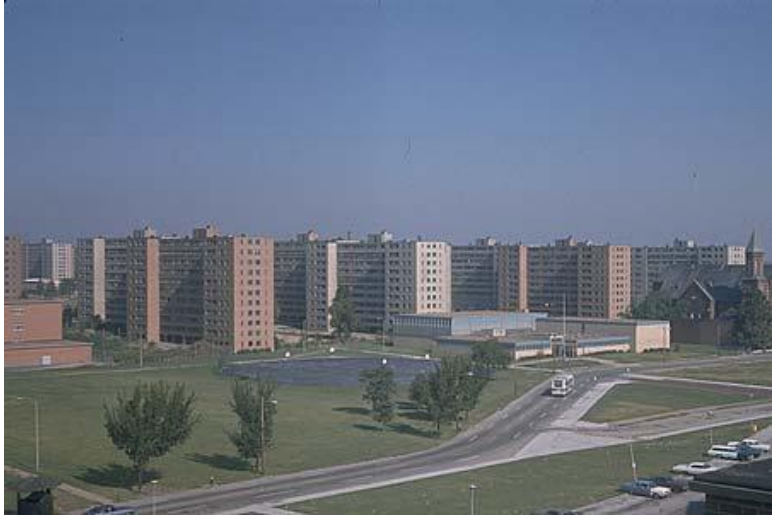

(a)

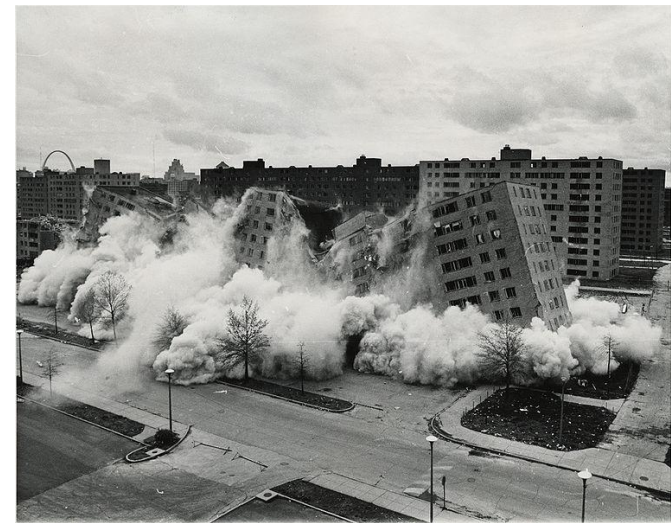

(b)

Figure 4. (a) Pruitt-Igoe public housing in St. Louis, Missouri, built in 1955-1957. Image courtesy of the U.S. Government; (b) Project demolished in 1972. Image courtesy of the U.S. Department of Housing and Urban Development.

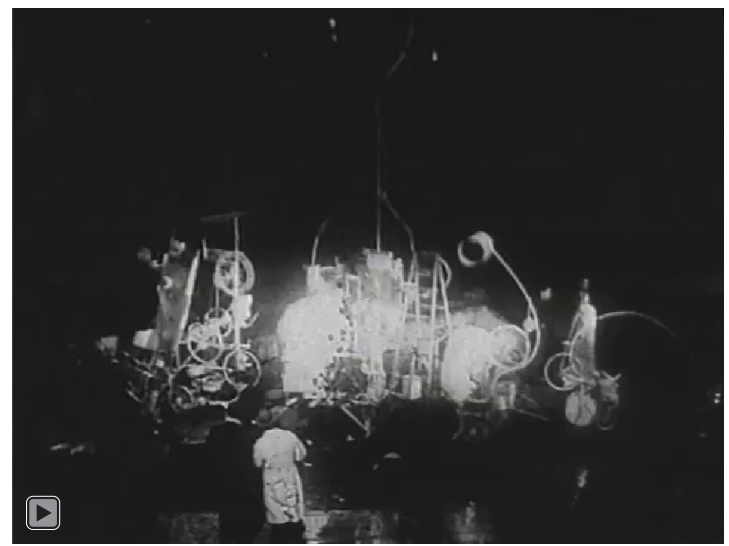

(a)

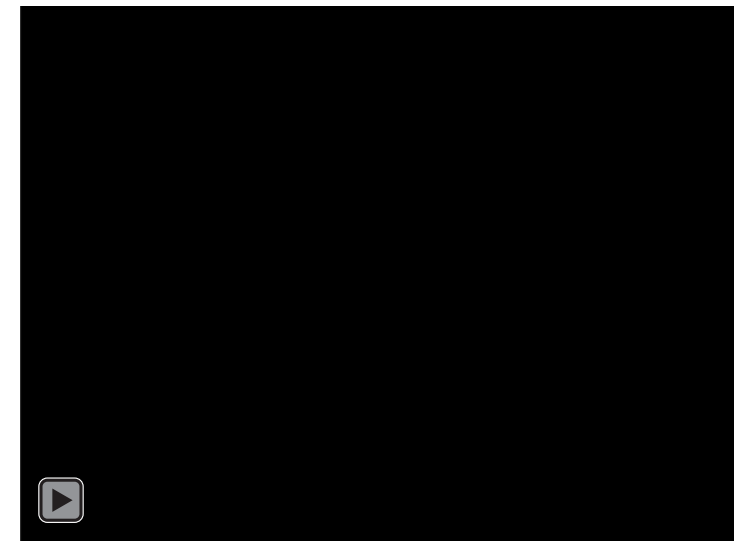

(b)

Video 1. (a) Tinguely's self-destructive machine, Homage to New York 1960. Video is a clip from BREAKING IT UP AT THE MUSEUM: A film by D A Pennebaker. Courtesy Pennebaker Hegedus Films. For more information on their films please visit PHFilms.com (b) Pruitt-Igoe Implosion. Video reproduced with permission from KWMU: St. Louis Public Radio. 
J.P. Sartre underlines that "man first of all exists, encounters himself, surges up in the world-and then defines himself afterwards." [3] (para. 9). By embracing a political choice and a new professional path, I definitely affirmed its potential value for the improvement of humanity. I tended at times to hide this freedom because it was quite difficult to assume. When facing oneself in the wide array of potential choices and values that present themselves, we have to face justifications or excuses. Man is defined only insofar as he acts and as he is responsible for his actions. It gives meaning to life.

\section{A Kinetic Project: Self-Help on Macro-Scale}

My Master's thesis at Massachusetts Institute of Technology in 1962 was the Boston Waterfront Renewal project. It included two thousand housing units, professional and commercial spaces, as well as parking. The big challenge for me was to determine the city-planning model on which to base my design. The private and government's high rise social housing built after the war brought great social problems, and were demolished as we have seen soon after because of the social problems they created.

\subsection{The Boston Waterfront Project}

Flexibility in design has been a constant in my practice, bringing about new opportunities for self-expression in urban living. Lewis Mumford has been of great influence. He wrote: "If man had originally inhabited a world as blankly uniform as a 'high-rise' housing development, as featureless as a parking lot, as destitute of life as an automated factory, it is doubtful if he would have had a sufficiently varied sensory experience to retain images, mold language, or acquire ideas" [4] (p. 76).

How am I to serve man without enslaving him? In this Boston project, like in the 116th Street East Harlem Renewal project ten years later, I turned from high-rise towers to ziggurat-type buildings, where each floor was recessed from the floor beneath, thus creating garden-terraces. The prospective inhabitants would be offered prefabricated "lots in the sky". They could buy or lease as much concrete floor space as they could afford and then determine the placement of walls and windows according to particular needs (Figure 5).

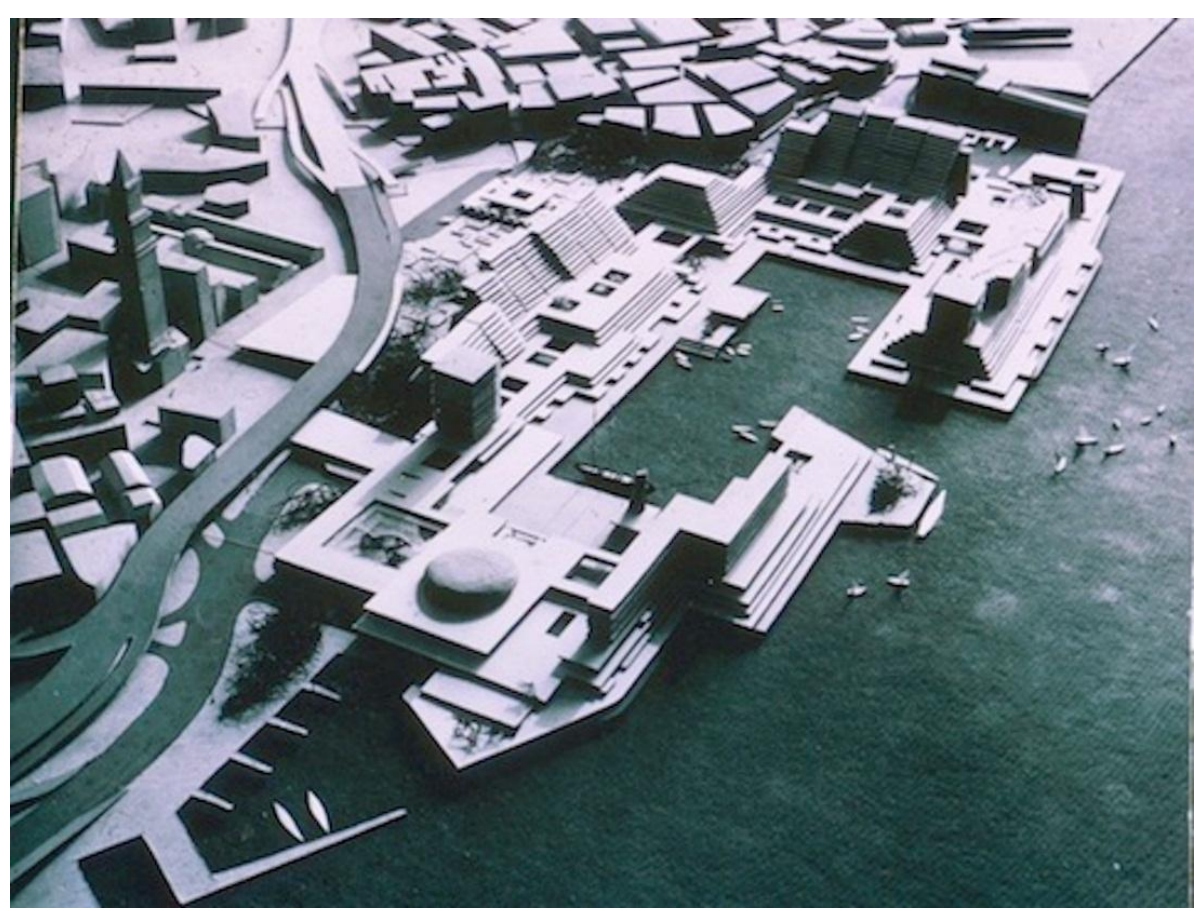

(a)

Figure 5. Cont. 


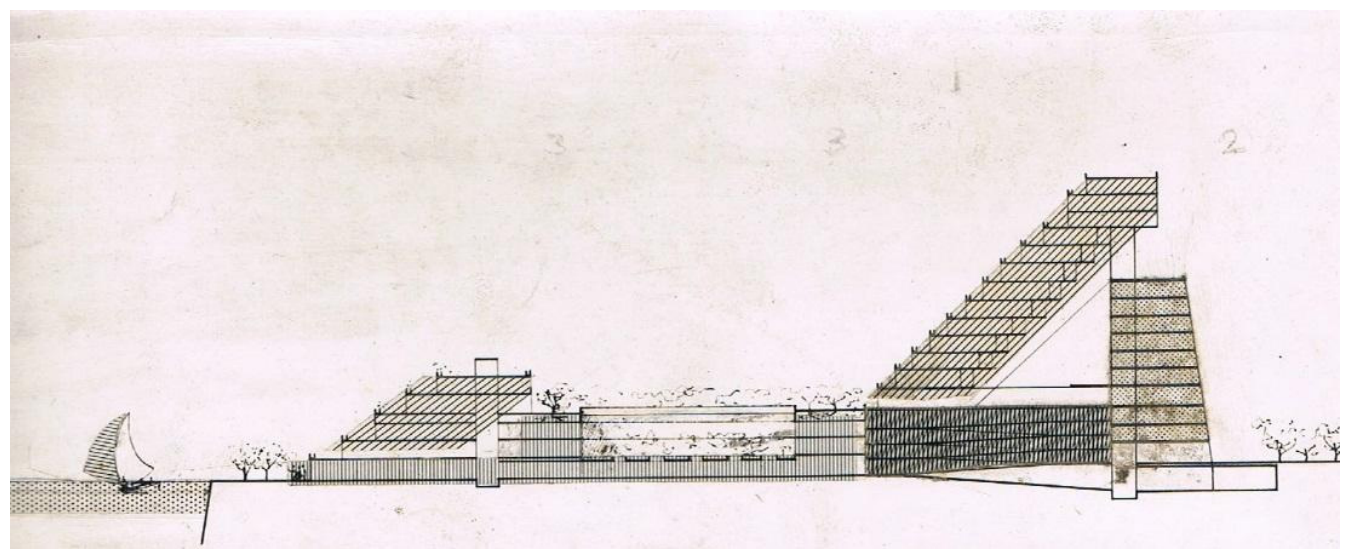

(b)

Figure 5. (a) Model of the Boston waterfront project, 1961; (b) cross-section of the Boston waterfront project.

In this way, organic diversity might be retained while allowing for today's sophisticated technologies. These stepped-back buildings, with their particular individual and very distinctive recessed façades, would all be private. All the terraces would be protected by planted greenery, involving man in his own space and in the creation of flexibility in personal design. The greater the choices, the more vitality there will be; people thrive upon having choices of motion left to their own whims.

The Boston project was inspired by the old time villages of Normandy, and particularly by the seaport of Honfleur (Figure 6). Individuals will generally feel better and in harmony with their environments when they are not being channeled involuntarily into undesirable surroundings. Thus, there is a higher flexibility to the user when there are several possible alternatives, that is, the same framework can be used in continually different patterns. This quality of changeability in one's surroundings provokes a stimulating enrichment for all.

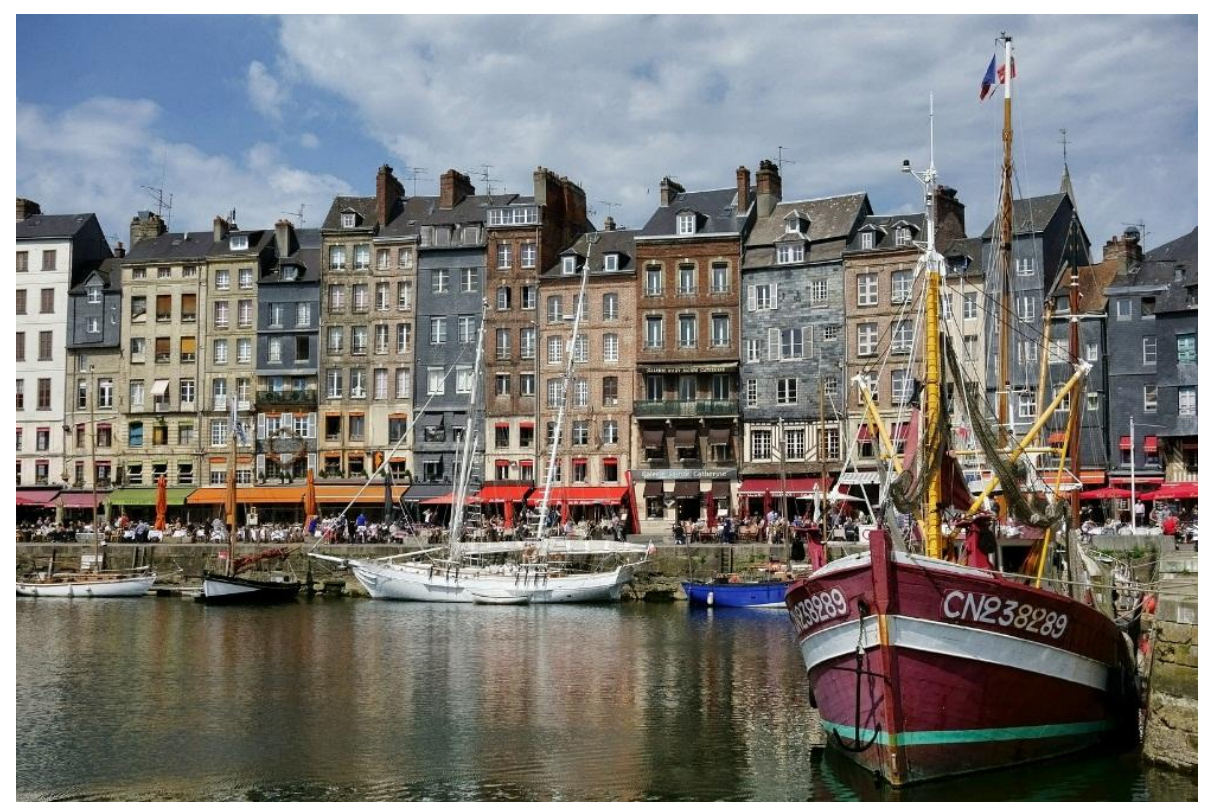

Figure 6. The Waterfront of Honfleur seaport in Normandy. Image courtesy of Philippe Vieux-Jeanton.

In Boston, I found myself reaching for the feeling of conviviality and well being one senses in the early historic port villages in France. There, self-made houses were tightly built around the 
harbor. Few were alike; some were modest with a single window on each floor, others wider and more generous. Each reflected the financial means, technical know-how, and personal whim of its builder. Poor or rich, all of these houses had a view of the marina. I was torn between the designer impulse to impose modernity and the desire to look back to my roots, being born in an adobe house built by my grandfather, and my personal experience growing up in a rather pleasant and entirely self-built village in Morocco.

In a highly industrialized age, how can one preserve the spirit of the personal and harmonious man-made settlements of the past into today's large-scale highly industrialized society and massive buildings? I believe that the overall planning of the macro-scale structure should be devised by the architect, leaving the micro-scale personal spaces flexible for individual expression, according to one's needs and means.

Such a deliberate kinetic architect-design concept of a macro and micro scale environment would take advantage of the modern techniques of mechanization. In so doing, devices of man-controlled flexible microstructures can be articulated within a more permanent mega-structure, allowing new opportunities for self-expression in urban living. In this way, the architect can provide for the development of diversity in design rather than imposing uniformity of habitat. This diversity was inherent to cities throughout history. It was the result of individual determination, an imponderable no architect can foresee.

\subsection{The Settlement House and Housing for the Elderly on East 116th Street: The Reason of How I Landed in East Harlem}

Almost ten years later, I advocated the same housing principles from the Boston project in East Harlem through a contract with the Borough of Manhattan President and the local Community Planning Board No. 11. As an answer to the necessity to increase density, I concluded that, "for urban life to be not only bearable but agreeable every apartment should have immediate access to an outdoor space one third of the apartment size. It is up to the planner-architect to build in dense urban areas multi-story concrete platforms with different setbacks so as to allow sunlight and air to fill every living area ... This extra space, currently not allowed by any low income housing standards, would be warranted by the economic gains arising from the lower, owner-completed construction costs" [5] (p. 36) (Figure 7).

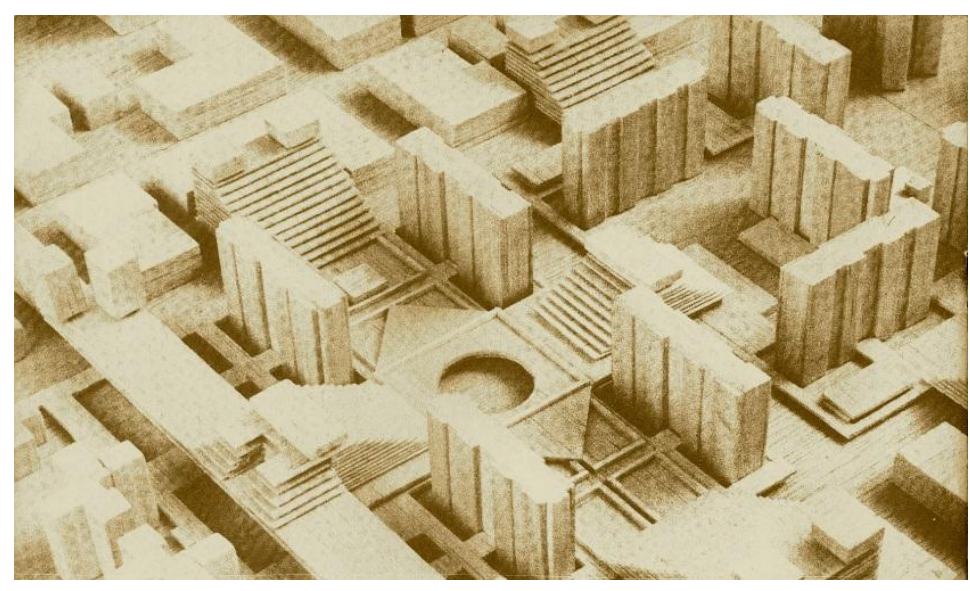

Figure 7. East Harlem project.

The Board of Trustees of a Settlement House in East Harlem needed new recreation facilities and they could not find the funds to rebuild them unless, as suggested by the State Housing Authority, they integrated it with 100 residential units for the elderly (Figure 8). For that effect, they acquired a couple of houses adjacent to the center to be demolished for the future larger project. Unable to pay professional fees for the preliminary architectural studies, the board offered me one of these houses in 
exchange for my feasibility studies, to use both as office and residence for my family. This was at once a fair and attractive proposal, and I moved from Philadelphia to East Harlem, New York in the spring of 1964 .

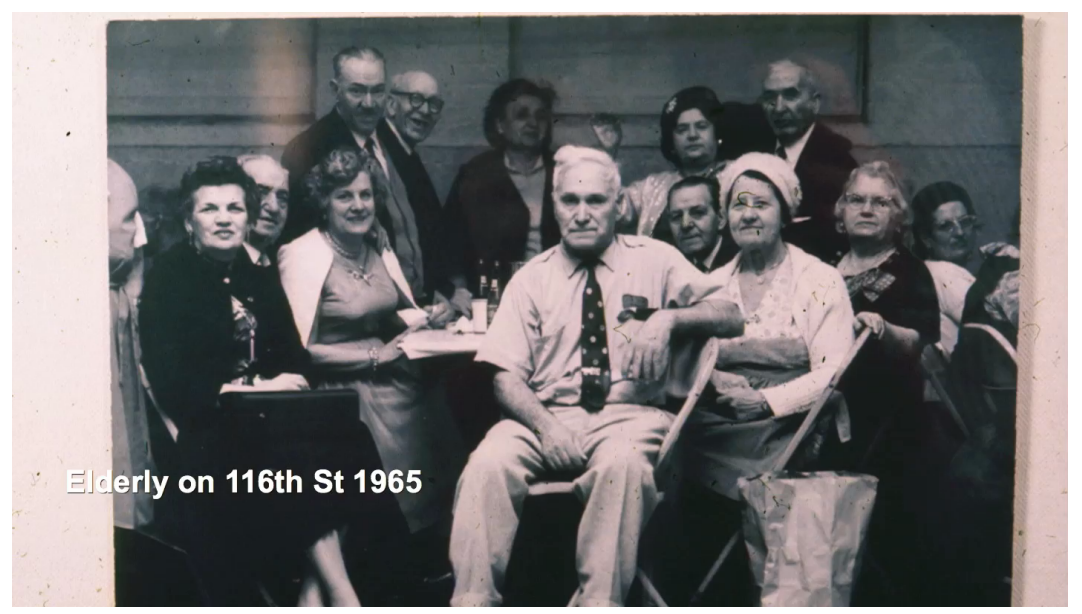

Figure 8. Elderly on 116th Street, 1965.

My work fell well within President Johnson's vision of the Great Society and his war against poverty. Johnson felt that poverty could be eliminated through education, job training and community development [6]. Through his Model Cities program, he offered support to the poor in framing and administering programs designed to help them help themselves.

After countless meetings with the Italian and Puerto Rican elders, we imagined a square tower, with a service core at the center, surrounded by an internal "street" naturally lit by, and open to, generous balconies at its four corners. On each floor, eight to ten housing units would share these balconies to encourage a village feeling among the friends choosing to live together (Figure 9a). This was especially important for the elderly who spend so much of their time at home. The Housing Authority was not used to having balconies for low cost housing. Their standards had already created drab and rapidly deteriorating housing projects, making them instant slums, disrespectful and lowering human dignity. They believed that their duty was to erect projects as gifts from the State to the poor, and my message was that their gift was a poisoned one.

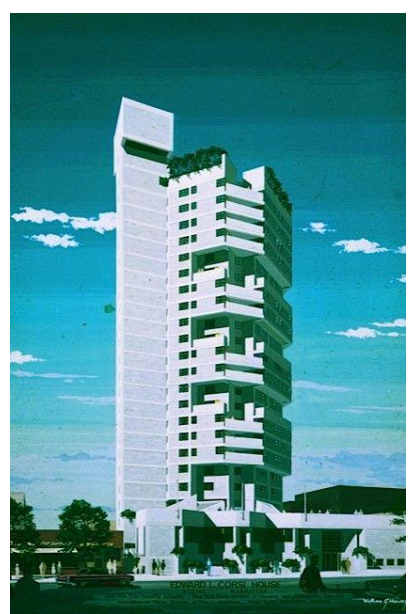

(a)

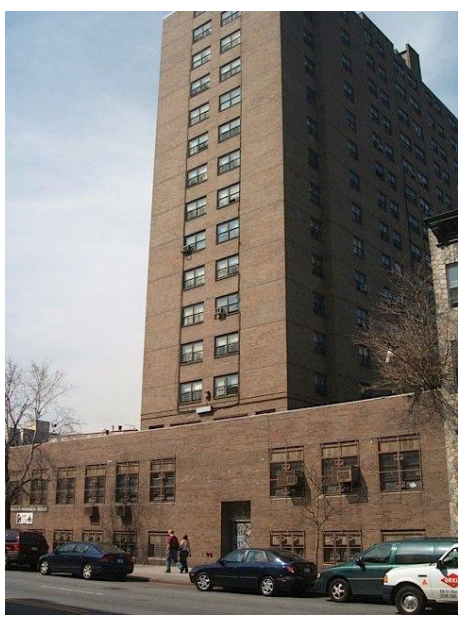

(b)

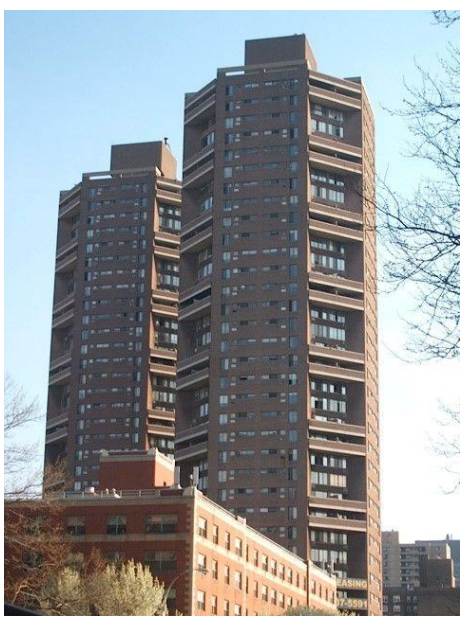

(c)

Figure 9. 116th Street East Harlem project: (a) Our 1967 proposed project to the NYC Housing Authority; (b) Final project built in 1972 by the NYC Housing Authority (c) A copy of our design was built by a New York architectural firm on 110th Street for a middle-income housing project in 1975. 
Hours of my time designing and negotiating towards a more dignified and convivial environment had come to naught. The New York Housing Authority found it insulting when I asked the "housing standards guardians" if they could live a week, a month, or even a single day in one of those instant high rise slums they were helping to promote? To their minimum standards I opposed minimum decency. After two years of a frustrating fight, I refused to associate my name with the final design (Figure 9b). In the meantime, thanks to the reproduction of our proposal in various architectural magazines, a New York architectural firm seems to have been inspired by our ideas for a nearby middle housing project on 110th Street (Figure 9c).

The desire of my students from the Pratt Institute to work directly with struggling communities on real issues, rather than abstract and irrelevant academic design problems, was overwhelming. It helped forge a powerful alliance between us all. This led to the adoption of a new philosophy of participatory and experimental education; a philosophy that, in time, became the model for a new form of professional practice closer to the people (it became known as advocacy planning). There was a call for greater professional accountability to communities and the need to engage people in the planning development processes that affected their lives (see Figure 10 for views of East Harlem life).

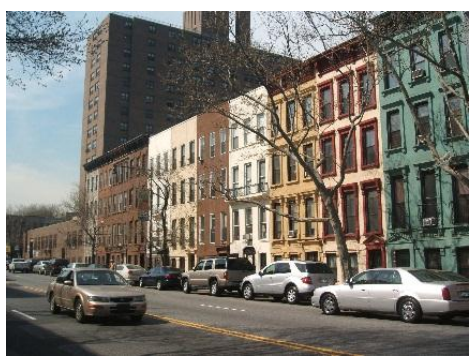

(a)

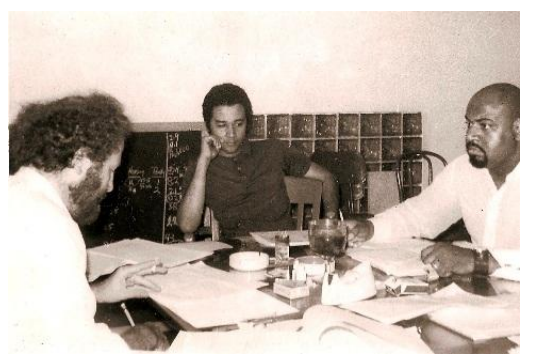

(b)

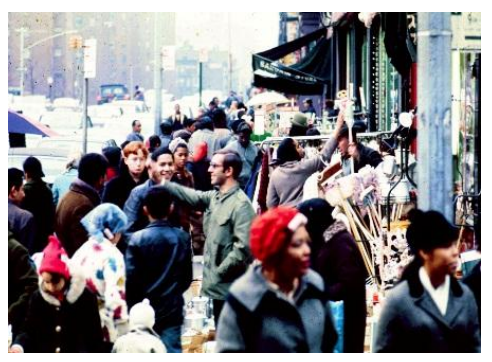

(c)

Figure 10. (a) 116th Street near 1st Avenue; (b) An office meeting; (c) 116th Street between Lexington and Park Avenues.

Through multiple actions with diverse groups, my office evolved into the "East Harlem Community Design Center". Special relationships grew as I came to know the Puerto Rican leaders better. I was consulted by them on the various problems that plagued Urban America. My Latin roots and my ability to speak Spanish were assets.

Our center was part of a movement created and labeled "Advocacy Planning". Its goal was to connect the interests of the powerless with the expertise of architects and city planners in determining the planning process and acting towards political effectiveness. It was a movement that spoke to my most profound sense of purpose and that increasingly drew me away from the cult of past masters, towards a more imaginative involvement with the needs of those who often were the dispossessed in society.

\section{Motion Determines Form}

As an urban planner, architect, and artist, my involvement in those years was manifold: to help people, whatever their socio-economic status, better understand the forces acting upon them, and to help them organize themselves so as to have a true say in the shaping of their immediate environments. In a time of rebellion, we insisted that the architect could fully function only if he is prepared to extend himself to activities that were previously considered beyond his realm of competence. I see advocacy planning as inspired by a new form of action in the urban planning and architectural fields.

In the medical field, a national conference, "Man, Mind and Medicine" to which I was invited in New York State, underlined in its conclusions a growing belief that patients should be regarded as unique, changing individuals and should be treated accordingly [7]. Likewise, through advocacy activities, architecture was gradually changing its focus by realizing its essential involvement with 
human life. "Form follows Function", coined by Louis Sullivan [8], the father of the American skyscraper, was a philosophy that has deteriorated into an obsession with efficiency ${ }^{1}$. While the form-follows-function school had rejected the notion of architecture as monument, it exposed and celebrated the mechanical innards of the building. This school of thought still is today object oriented, rather than people-oriented.

I contend that Form follows Movement, meaning the actions of people, not machines, should determine the future. Thinking in this way leads us to view our sometimes decaying and dehumanized urban environment as a living organism because motion is the prime characteristic of life. Mobility has always been the very essence of human association: everything that moves is alive and anything that lives moves. In the nineteenth century, the French mathematician and zoologist Frédéric Houssay, established the formula: FORCE ... > MOTION . . > FORM [9]. Accordingly, force generates form through motion, and motion determines form through all of life's processes.

It is my intent to show how the movement leading to participatory processes, and the engagement of people in every field, leads to the emergence of better places and seeds the civil society structures upon which communities are sustained and democratic institutions can be built. In a highly industrialized age, how can one reduce the needs of a sizable portion of the population to large-scale prison-like housing projects? Architects should be aware that the greater the choices, the more vitality there will be, for people thrive upon being left to their own whim in making choices of motion. How can one preserve the spirit of the intimate and harmonious relationships of man-made settlements of the past in today's large-scale society?

\section{The Vital Sense of Mystery in the Environment}

Man finds his environment challenging and exciting when it contains a mysterious sense, when it provides for change, surprise and variety. Such mystery occurs in nature with all the elements: the movement of the wind, changes in weather and ever changing clouds, heat and cold, light and darkness. What is more kinetic than moving clouds, and even more during sunsets? (Figure 11).

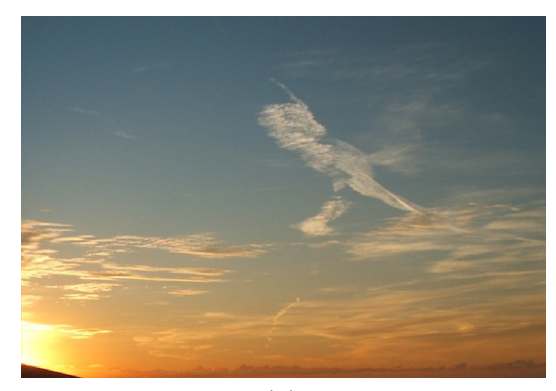

(a)

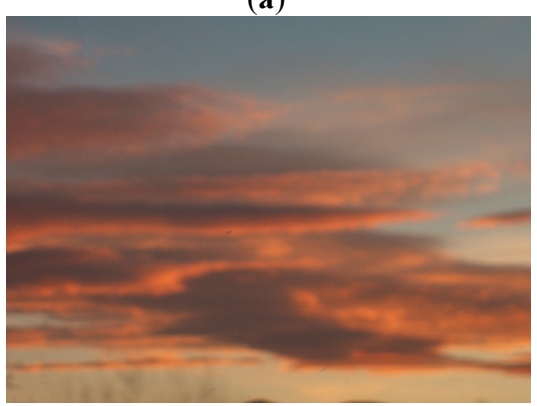

(c)

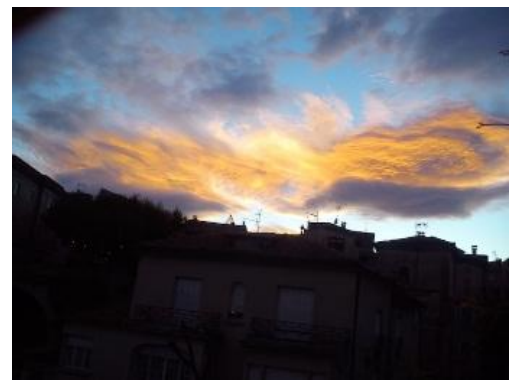

(b)

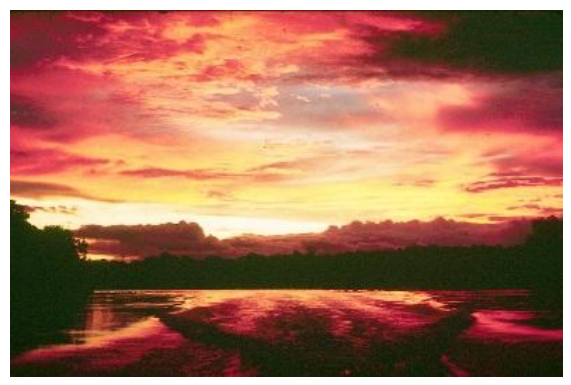

(d)

Figure 11. Cont. 


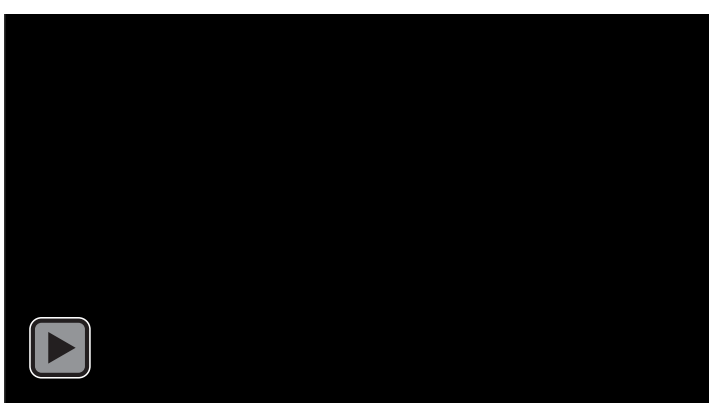

(e)

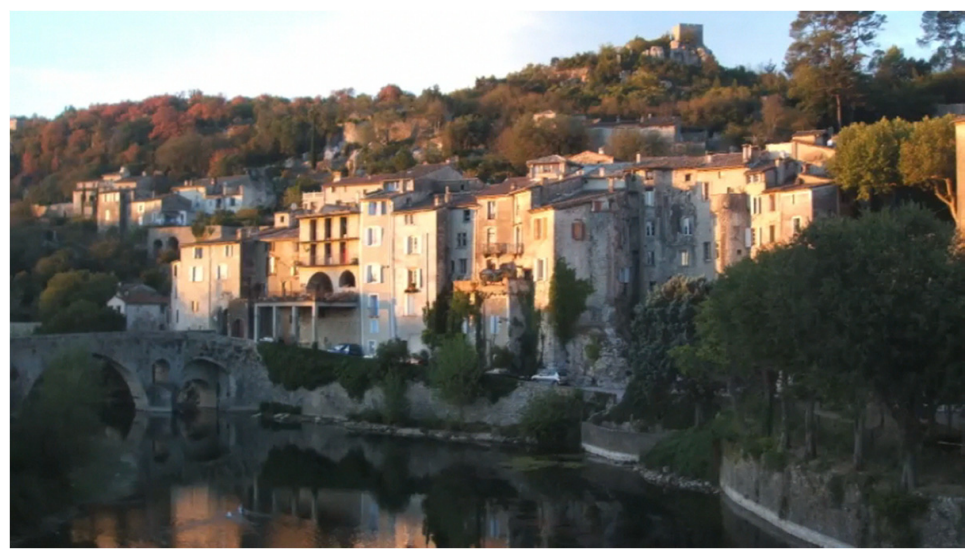

(f)

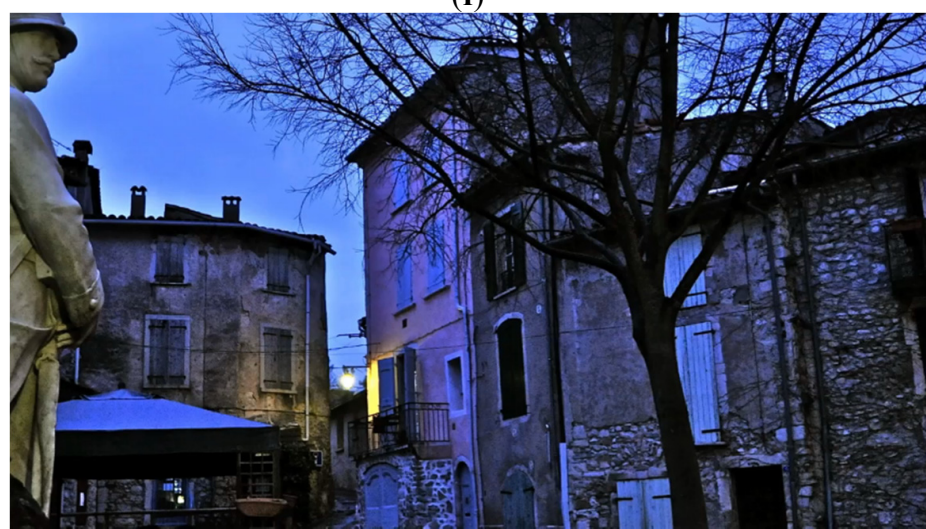

(g)

Figure 11. (a-d) Kinetic clouds. Images reproduced with permission from Roger Katan. (e) Inspired by the clouds, I did a video called "Sunset at Dinard" (2015). Video reproduced with permission from ANM Plasticolor (f). The village of Sauve by day. Images reproduced with permission from Roger Katan (g) Village by night. Images reproduced with permission from K. Seli.

Similar to sunsets, it is a surprising kinetic experience to walk through a medieval village with its visual diversity. The surprise in the medieval village could equate the sensations one feels in optical art. Here, modern man is transported back through the mysteries of time. Such cities were, and still are, puzzling to their inhabitants because they are asymmetrical, juxtaposing tiny individual dwellings with cathedral structures so immense that one man could not perceive them in their entirety without moving in and out of them (Figure 12).

By moving around and viewing such a huge structure from many different vantage points, one develops a variety of perceptions, each dependent on the particular situation of its viewer. One could look at the altar from the first pew, or from the balcony, or from behind the cathedral through the stained glass window, and each view would reveal a different perspective of the same place. Likewise, two different people could come to the cathedral at two different times of day or during different seasons and they might walk slowly through the front door or enter from the side, alone or with others, or one might stop briefly, another linger for hours. The cathedral is mysterious 
because each person experiences a different perspective and mood through a variety of light and darkness, colors, heights, shapes, and corners.

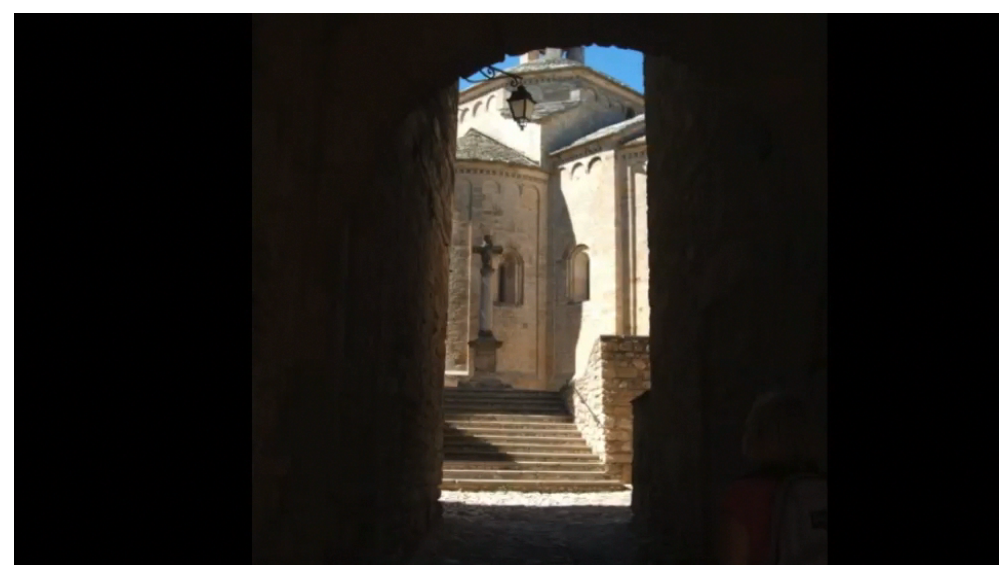

(a)

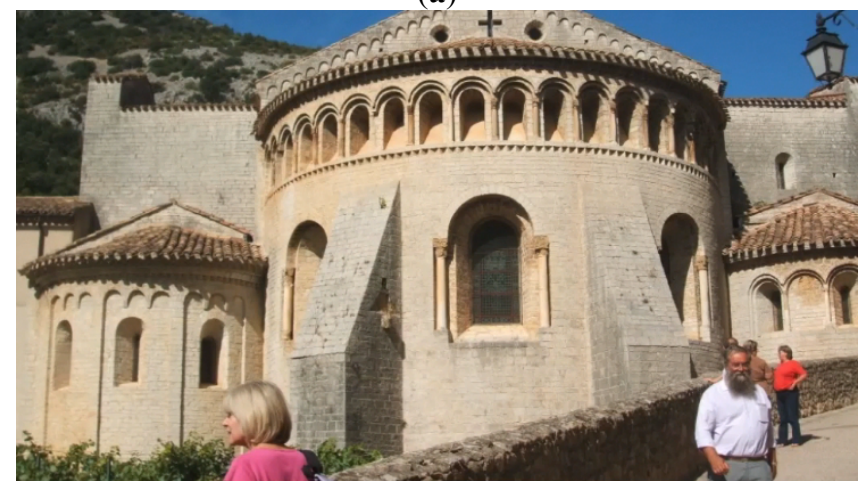

(b)

Figure 12. (a) Sense of mystery exemplified in moving through the medieval cathedral of Saint Martin de Londres; (b) Saint Guillem du Desert.

\section{First Kinetic Period: Mecanographs as Action Art, 1962-1964}

My first machine-produced images were created in 1962, while working with Louis Kahn in Philadelphia. A false movement occurred while working with a blueprint copying Diazotype Print machine. I was in the process of reproducing an architectural drawing made on tracing paper: the chemically coated copy paper accidentally crumpled itself, turning the quadrangular image of the plan lines into a fantasy of forms. A technique was born: machine-made art (Figure 13). The art was the result of an interaction between the movement, the artist and the machine. I called them mecanographs or action graphs; they distinguish themselves by the nature of their source. The accidental images produced explode into a play of forms of associative power, similar to the Rorschach, with the diffused patterning of a Pollock. In the beginning, rescued print paper from the wastebasket was crumpled in different ways and passed through the chemical process. Manipulation of these images, because of the paper's small size, was at times limited to cropping and reprinting, and most of the time fragments were composed and pasted into large collages. I went to large size print paper when asked to exhibit at the Osgood Gallery in New York. 


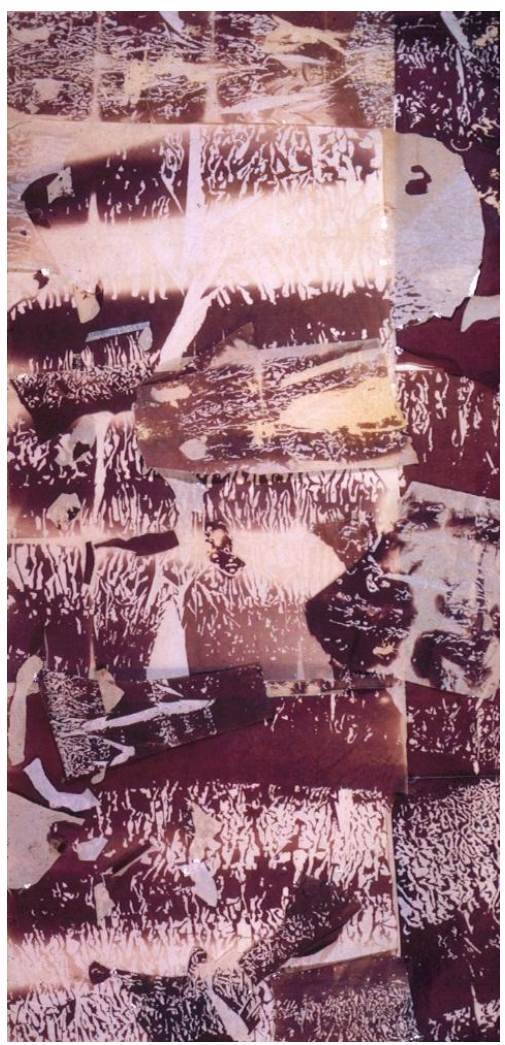

(a)

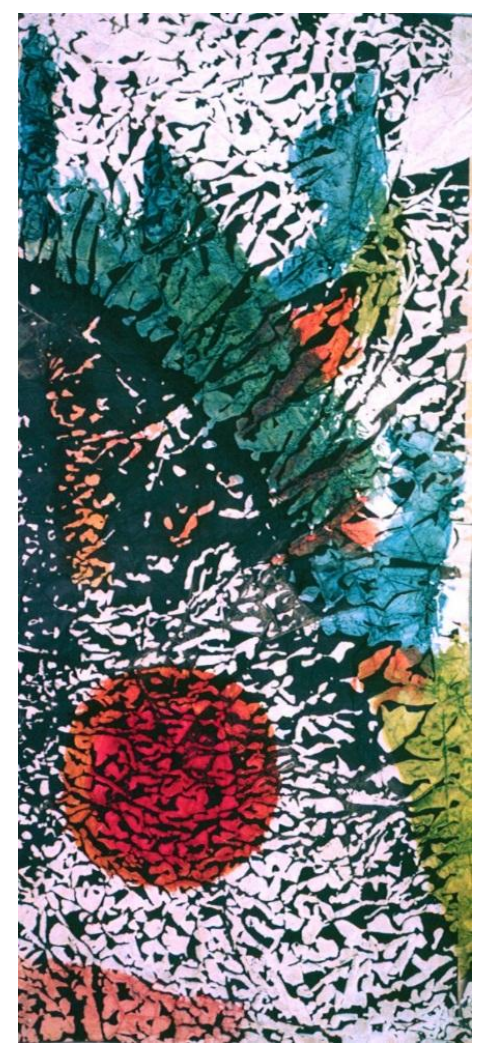

(b)

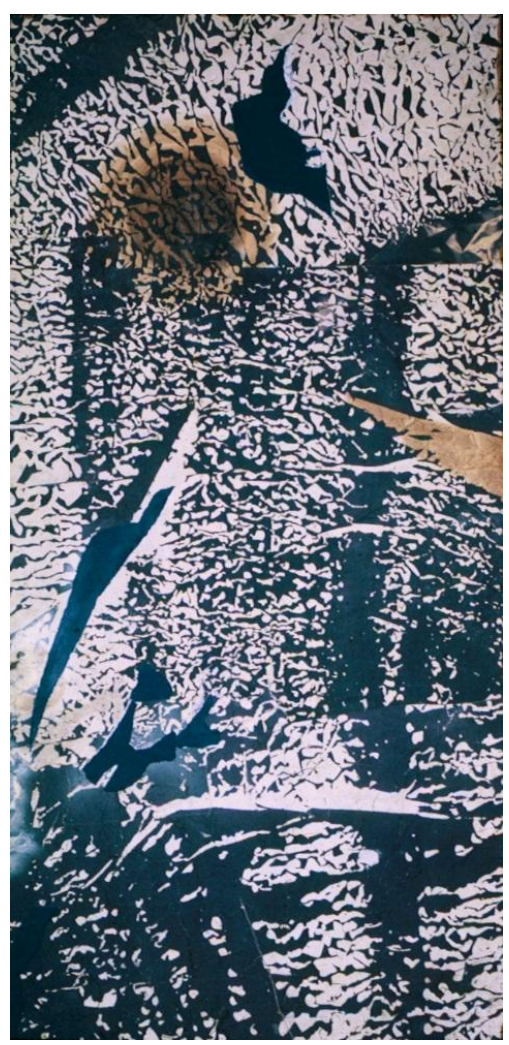

(c)

Figure 13. Examples of machine-made art: (a) "Alexandre Nevsky" $200 \mathrm{~cm} \times 0.95 \mathrm{~cm}$; (b) "Sunrise" $150 \mathrm{~cm} \times 0.40 \mathrm{~cm} ;(\mathbf{c})$ “A. Nevsky No2" $180 \mathrm{~cm} \times 0.48 \mathrm{~cm}$.

\section{Second Kinetic Period, 1965-1975}

To alleviate my frustration of not being able to build immediately the buildings we designed together with the East Harlem community groups, I began sculpting imaginary towns with street-found objects, giving them a new life. My work with the community was paralleled with the research of forms and the movement of light in my artwork. I created imaginary structures with recycled objects like egg cartons and other materials. Once embedded with resin, these objects were sculpted to receive and emit light, becoming imaginary towns and villages. During this same period, I was linked to the New York art world where different movements like Abstract Expressionism, Pop Art, and a Renascent Kinetic movement took place.

I became focused on transforming egg cartons into cityscapes and mega-structures (Figure 14a-c). By making slight changes in the repetitive mechanical forms of papier-mâché cartons-cutting bridges, opening slits, shading recesses and placing blinking multi-colored lights behind-I captured the excitement of the city at both large and small scales. Like cities, these constructions were a receptacle of natural light during the day, and became light-transmitters at night. Once painted acrylic white, in daylight they were reminiscent of the repetitive structures of Arab villages of my childhood in Morocco. At night, they had the dark shadows, flashing neon lights, and quick vibrations of the American city (Figure 14d-f). They seemed to bridge the world of my childhood with my new American world.

From the mid-1960s to the mid-1970s, I became involved in the New York art scene. I followed the traditional Tuesday night ritual of meeting friends at gallery openings and making contacts to show my compositions. Mrs. Helen Varian, then director of the Finch College Museum of Art, became a fan of my work and introduced me in the New York art circles. I took part in several group shows and sold a few pieces to complement my East Harlem income. Thanks to her appreciation of my work, 
I was selected in national shows in company of the avant-garde of American Art. One of my greatest successes was an invitation to participate as one of ten kinetic artists in one of the most prestigious New York galleries at that time, competing with Denise René: the Howard Wise Gallery. Being the least known artist in the group, my work hung with the works of Alexander Calder, Jean Tinguely, Louise Nevelson, and Len Lye.

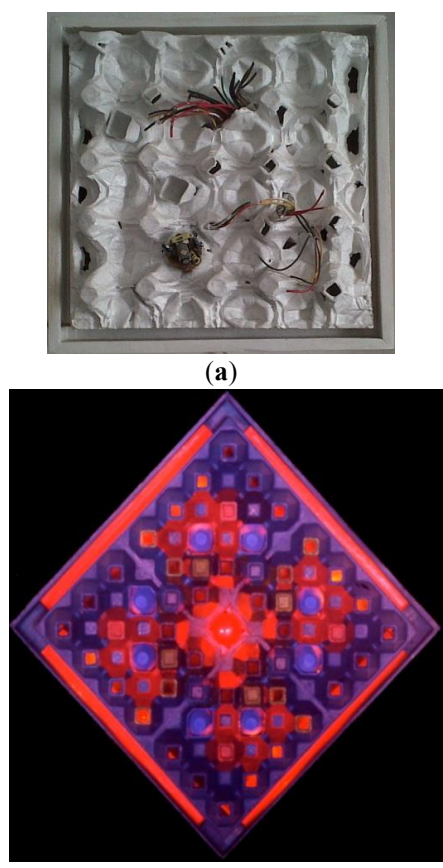

(d)

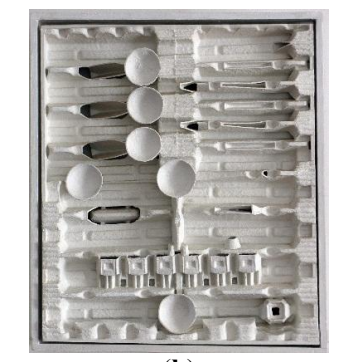

(b)

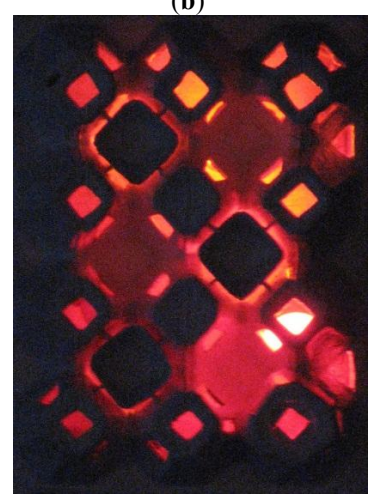

(e)

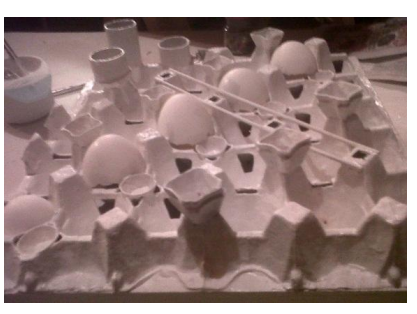

(c)

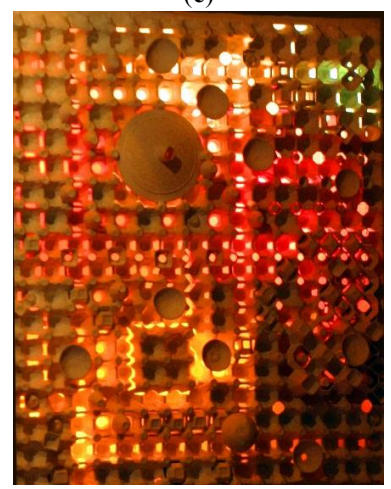

(f)

Figure 14. Light boxes (a) "September 11, 2001", $30 \mathrm{~cm} \times 30 \mathrm{~cm}$; (b) "Downtown NY, 1969", $52 \mathrm{~cm} \times 45 \mathrm{~cm}$; (c) "Detail of composition No. 8" 1971, $125 \mathrm{~cm} \times 65 \mathrm{~cm}$; (d) "Red and Blue Square" 1968, $41 \mathrm{~cm} \times 41 \mathrm{~cm}$; (e) "Lightbox No. 4" 1968, $29 \mathrm{~cm} \times 16$ cm; (f) "Roselight for Whiteville" 1972, $95 \mathrm{~cm} \times 72 \mathrm{~cm}$. Images reproduced with permission from Roger Katan.

In the art field, the participatory movement broke chains from the past and joined those kinetic times, allowing many new ideas to break through and develop. During my teaching years, I had long conversations (sometimes debates) with Sibyl Moholy-Nagy, who was also teaching Art History at Pratt Institute. She could not understand nor accept the students' involvement in poor communities. I felt this contradicted her famed husband, Lázsló Moholy-Nagy, with his breakthrough "New Vision" of 1928. He had inquired into the possibilities of forces producing an endless transformation of expression in which the spectator could be immersed and would experience "a heightening of his own faculties, becoming himself an active partner with the forces unfolding themselves!" [10] (p. 50).

\subsection{The Art Scene in New York in the Mid-Sixties}

My close friends in the art world at that time were Allan Kaprow and Len Lye. I participated in a number of Allan's "Happenings" when he pleaded for "concrete art" built from everyday material. He coined the term Happenings to make people forget about the artistic habits linked to the transmission of savoir-faire [11]. His acts of performance had no beginning and no end, and didn't impose a hierarchy between the artist and his audience. For the first time, he stated that craftsmanship and permanence should be forgotten and perishable materials should be used in art [11]. In Kaprow's Happenings it was the audience's actions and reactions that gave a unique character to the produced artwork.

His attempt to integrate art and life attracted him to my office in East Harlem. It must have been like large-scale Happenings that improved poor people's lives for the long term rather 
than the gratuitous street happenings that impacted and surprised the audience for a short time. Allan's multiple visits to my East Harlem community project showed his active interest in my way of involving people in having a say in their everyday environment. He must have appreciated the difference between a group engagement within the art star system, and the sustainable participative actions of community members in improving lives within their immediate environment.

In October 1966, I was invited to debate with Robert Smithson and Allan Kaprow on the topic "What is a Museum?" According to Smithson, "the reason people do go to museums is that they imagine they are going to get something out of these paintings ... It is a fulfilling sort of thing. This is the old idea of what was expected of traveling ... This notion, I'm afraid, has had it. It has its origin in the mind and not in nature. I think the mind is only referred to today in terms of mental illness. It seems that psychiatry has done a lot to encourage this thought; out of sickness comes this creative urge with its highly organic metaphors .... They try to bring better life-fulfillment to people, but they just bring a nostalgia for the 'finer' things of life" [12] (frames 1080-86). I answered that the museum in the European environment is more conducive to art appreciation or life appreciation because there, art is part of life. You can tell villagers about the nature of space. The pleasure that society brought into making and shaping forms has turned the cities into museums, in a way, because every single piece of such a village is an artist's thinking [12].

\subsection{Len Lye and the Kinetic Museum}

Len Lye and I used to go to mid-town and downtown gallery openings together. He often came to visit me in my office and later, in the mid-sixties, we designed his museum. He repeatedly told me one of the stories from his New Zealand childhood while walking together in East Harlem, or midtown Manhattan. He remembered kicking far away an empty tin can he found on his way, tumbling loud in a street. That sound and its echo stuck in his head. So he tried to create a sculpture that would symbolize the sound, the shiny twitch of vibrating light into the space ahead. This obsession became his impressive Sea Serpent, which I saw in a midtown gallery. It was a stainless steel band six inches wide and some twenty feet long, tied to a motor that gave it a strong impulse, sending the shiny snake waving with an impressive, unforgettable sound. When in movement, it reproduced the shiny tumbling can sound of his childhood (Figure 15).

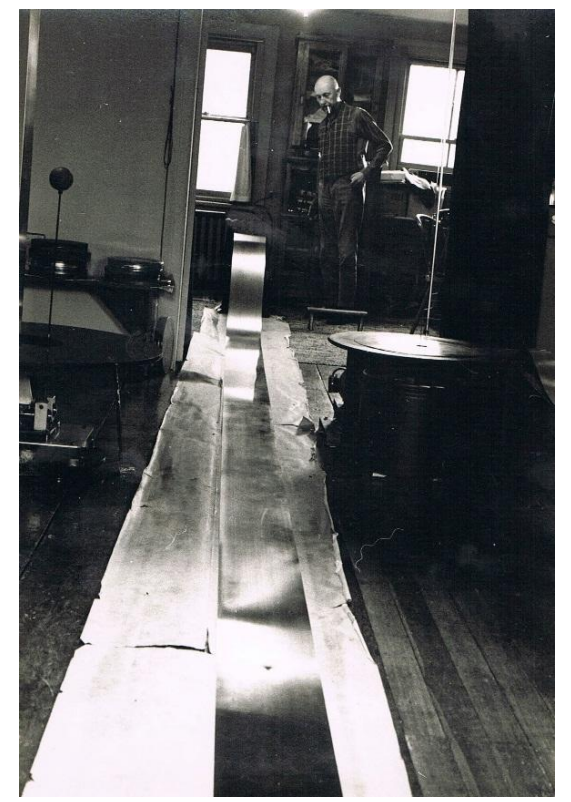

(a)

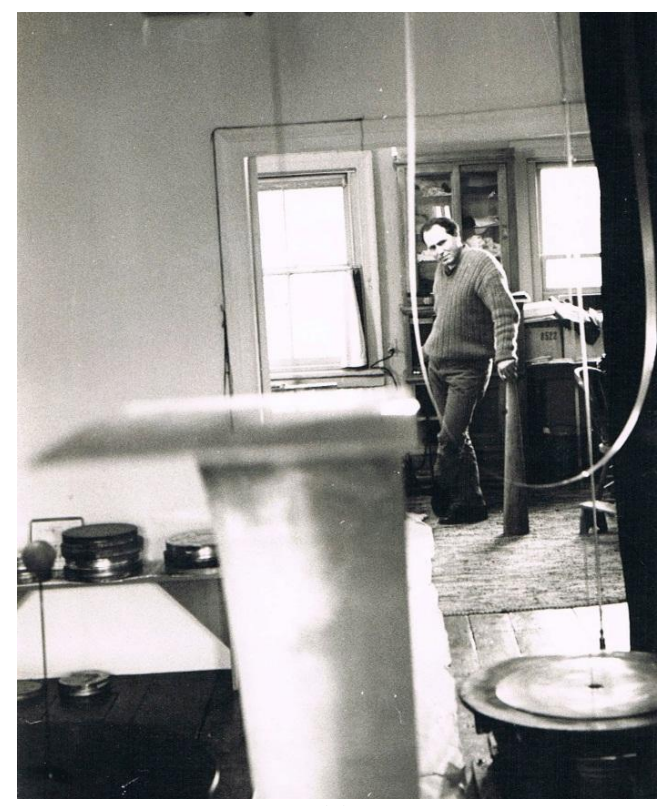

(b)

Figure 15. (a) Len Lye and (b) Roger Katan with Sea Serpent in Len Lye's studio, New York, 1966. Images reproduced with permission from Jon Narr. 
Years after, the sound of that can was transposed into his kinetic snake sculpture in the center hall of the proposed kinetic museum we designed together. His sense of movement was always kinesthetic and physical (Figure 16). In a paper he wrote in 17 October 1965, he seeks traces of motion everywhere:

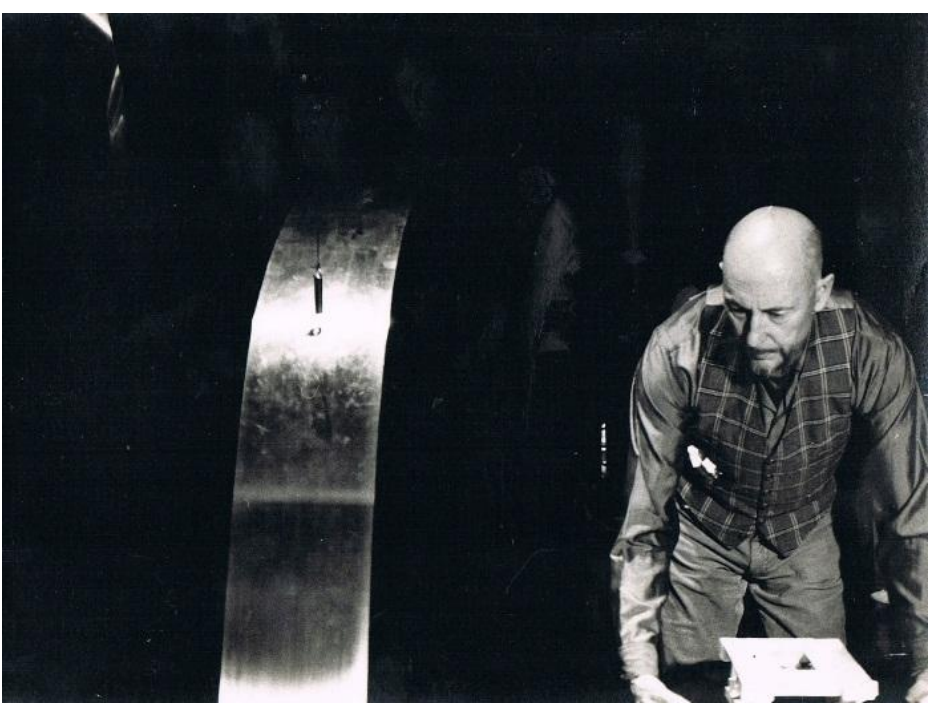

(a)

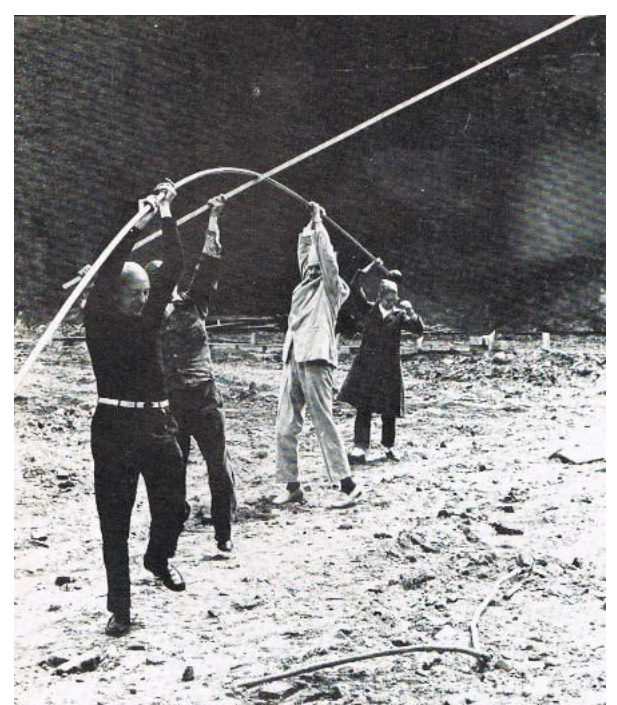

(b)

Figure 16. (a) Len Lye's Sea Serpent; (b) Trying a new idea with friends, 1966. Images reproduced with permission from Jon Narr.

The personal exercises for getting to the core of motion are not given as sure-fire guides to the practice of kinetic art. Each student will have his own anatomical cast of temperamental affinities with aspects of motion, such as weight, poise, balance, gravity, magnetism, energy. Each artist best knows where the shoe of his creative imagination most pinches. The kinetic student has to cobble his own. Unlike the other arts, there are quite a few shoes around to try ... Although realistic and abstract images appeared in cave paintings around fifteen thousand years ago, it took until this past century to discover the kinetic imagery of the art that moves. This conveys the fact that if we had taken the aesthetic quality of sound as much for granted as we have taken those of motion, we would have no music ... Whereas the artist in static art freezes whatever object or figure he, or she is representing, capturing a changing mood, a particular landscape, holding the emotional mark of the creator, the kinetic artist will compose motion. Composing motion can be inspired by whatever events that happened in one's life, particular moments important enough to express in whatever moving form that will best represent it ... Not only can we be made to feel the might and grandeur of energy in motion; the kinetic artist can make things seem to float as light as a feather, flop and flutter in butterfly fashion, hover and dart like a humming bird, or sway and sigh like rushes beside the water [13] (pp. 3-4).

Just as musicians compose sound, he wanted to compose motion. Through some of his kinetic sculptures, he wanted to make wind motion visible. His creativity was so endless and contagious that he easily convinced me to help him design a kinetic museum where his major work would be in the center of the museum: a series of seven stainless steel Sea Serpents in violent motion and musical cacophony. Because of the drama and the size of this project, the museum would be built around his centerpiece (Figure 17).

In 1966 I joined forces with Len Lye to determine what positive attributes a Museum of Kinetic Art should have. We defined the kinetic movement in three aspects: illumination, sound and physical movement, or any combination thereof, realizing that all of these aspects would have to be incorporated in the structure. From funnels of sound attracting the spectator to a plunge into darkness, before entering the central hall of 100 by 200 feet, to be confronted with Len Lye's enormous Sea Serpent 
piece. He would then be led through a series of different spaces with kinetic displays in controlled environments. Included in these areas were planned a permanent exhibit tracing the history of kinetic art, and special spaces and facilities for showing abstract and avant-garde movies with conventional and warped surface projections. The only break from these intense experiences would be the view of the sky changing clouds at roof level, and of the surrounding environment through peepholes on the sides, around a large pool with kinetic water sculptures. The sum effect of the whole would be a kinetic sequence of constant movement change (Figure 18).

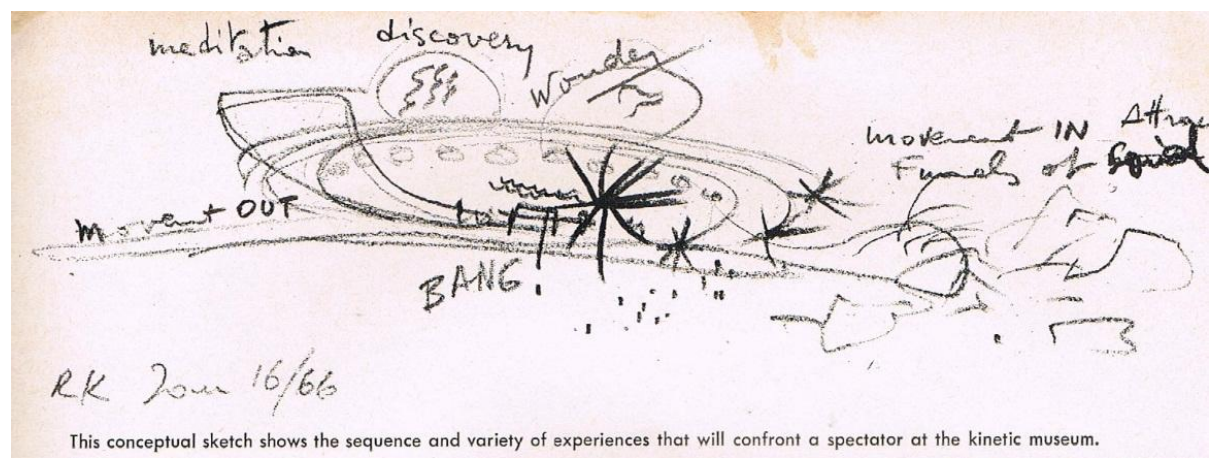

Figure 17. Conceptual sketch of the Kinetic Museum. Original sketch by Roger Katan later published in Art Voices, Summer, 1966. Image reproduced with permission from Roger Katan.

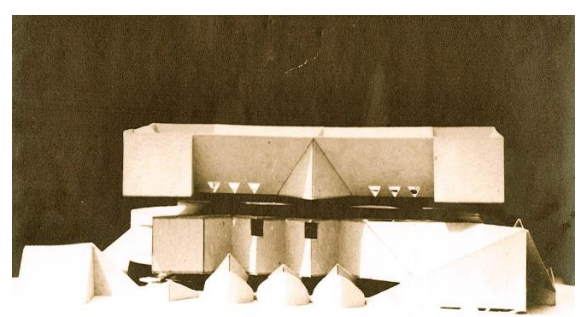

(a)

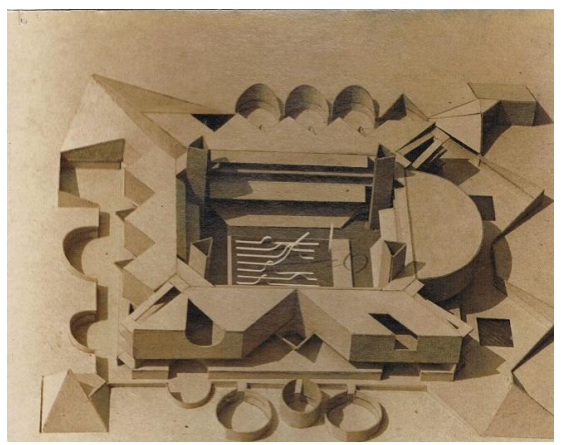

(c)

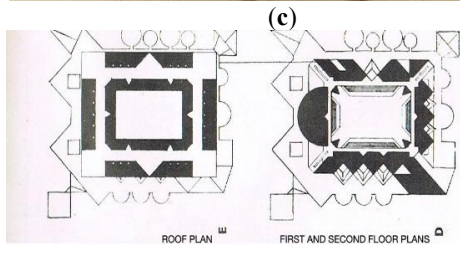

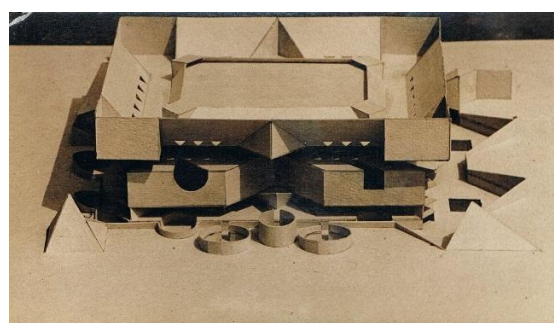

(b)
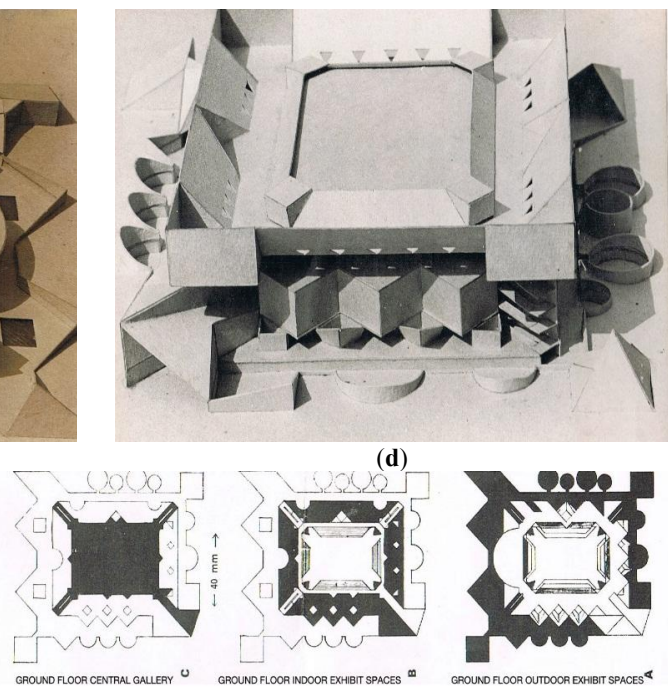

(e) (d)

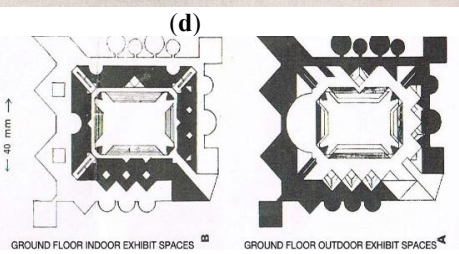

GROUND FLOOR OUTDOOR EXHBII SPACES

Figure 18. Len Lye Kinetic Museum Project: (a) Eastern Façade; (b) Roof and Eastern Façade; (c) The central space with the moving Sea Serpents; (d) Three-fourths perspective showing the Western Façade; (e) Floor plans (from left to right) of the roof, first and second floor, ground floor gallery, ground floor indoor exhibit spaces, and ground floor outdoor exhibit spaces. Images are by Roger Katan and were later published in Art Voices, Summer, 1966. Images reproduced with permission from Roger Katan. 
This project was never built. The designs were published in the magazine Art Voices under the title "Architecture and the Kinetic Movement: The work of Roger Katan" [14].

\subsection{Movement and Form in the City: Gateway Proposals for Manhattan}

By the end of the sixties up to the mid-seventies, commuting from East Harlem in to Brooklyn or to New Jersey involved travelling through a jungle of expressways and roadways tearing into Manhattan Island's urban fabric to get access to bridges and tunnels. Surrounded by the East River and the Hudson River, Manhattan residents did not have any access to enjoy their closeness to water. This led me to a series of proposals of gateways into Manhattan Island to the New York City Planning Commission.

Coming from Europe, with its richness of medieval cities, I found it hard to accept the waste of land devoted to chaotic incoming or outgoing roadways around Manhattan's access to bridges and tunnels. Access and movement through the massive walls of a medieval city was a grand and guarded event. That was the time when pace, identity and interrelationships of functions were tightly knit in a cluster of human scale. It was the time of what we might call the pedestrian city. Today the human scale has given way to a machine scale: accelerating pace, tearing down identity, and scattering functions.

As the Industrial Revolution freed men to cover greater and greater distances, it brought compartmentalization into urban life, effectively destroying the form and the meaning of the walled city. The twentieth-century city emerged, choked with industry, surrounded by city-escape homes, and exploded by the faster means of transportation. Man was inebriated with distances spanned and speeds attained. Bridges and interchanges were flung up in response to the mechanical needs of more effective movement. Perceptible movement and environmental changes occur in speed, space, sound and smell. The driver passing from one realm to the other frequently experiences disorientation and doubt amidst the assault of directional indications, for now the transition is accomplished grayly, with neither the excitement of dramatic emphasis nor the clarity of ordered analysis that such permanent infrastructure would command.

\subsubsection{Brooklyn Bridge Gateway}

In 1883, after two decades of effort, the Brooklyn Bridge was opened as the longest single-span suspension bridge in the world (Figure 19). The dream to link the two cities of New York and Brooklyn by a technological masterpiece was realized. In one structure all modes of traffic across the East River were accommodated-railroad, pedestrians, and carriage (later automobile). The bridge extended into the urban fabric, arching towards both center hubs, where each kind of traffic was dispersed.

With the outburst of automobile traffic that later poured into narrow streets, the New York City Planning Commission's solutions failed to solve and circumscribe the problems generated by traffic activity in the surrounding area. Its 1966 plan was without vision. Like the Lower Manhattan Plan of the same year [15], when dealing with traffic in the whole area, and particularly with the approaches to the Brooklyn Bridge, it ignored the roots of its problems. The visual confusion offered to the driver was one of fragmentation and chaos. The roadways opened and suddenly closed. Darkness succeeded light. From blind corners to open skyways, the visual landscape was disjointed as if brutally interrupted by unnatural shifts. The process of orientation was, and still is, exhausting for the driver. Conflict is found on the ground between types of movement: between vehicles and pedestrians, and among vehicles themselves.

The advantages offered by a compact multi-functional gateway become clear in comparing its land use requirements with those of the City's plan for the same area. As can be seen in the City's proposal (Figure 20), space taken up by present and projected roadways (in red) amounts to 11 acres. The entire gateway structure would, in my 1969 proposal, use only approximately 31/2 acres, thus freeing almost eight acres for new civic purposes, such as a Civic Center. 


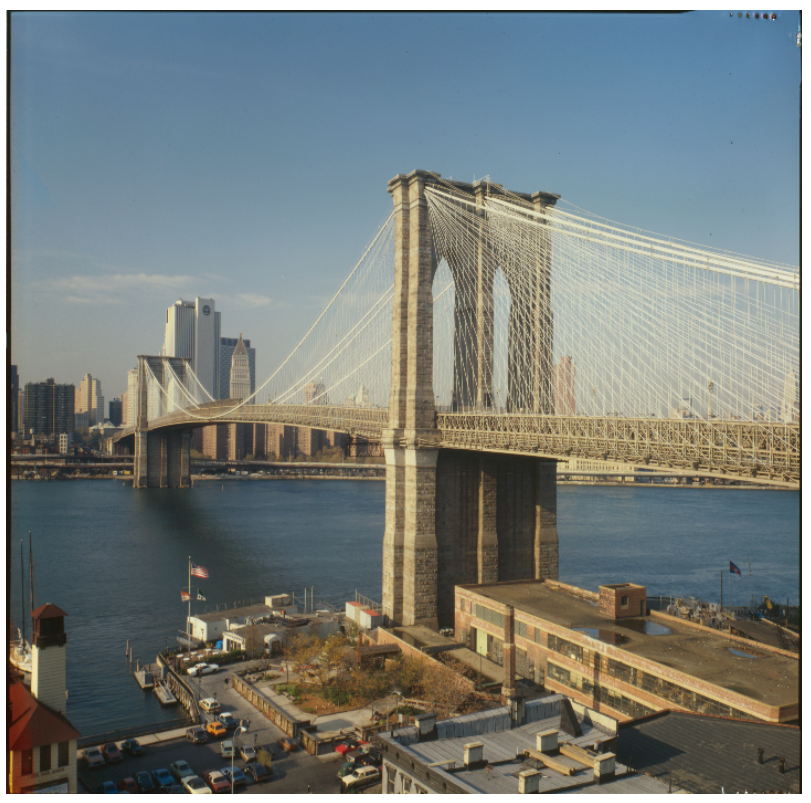

Figure 19. Brooklyn Bridge. Image courtesy of Library of Congress (US).

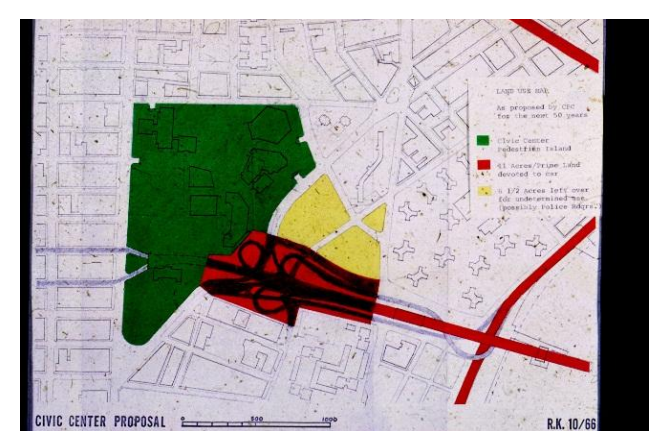

(a)

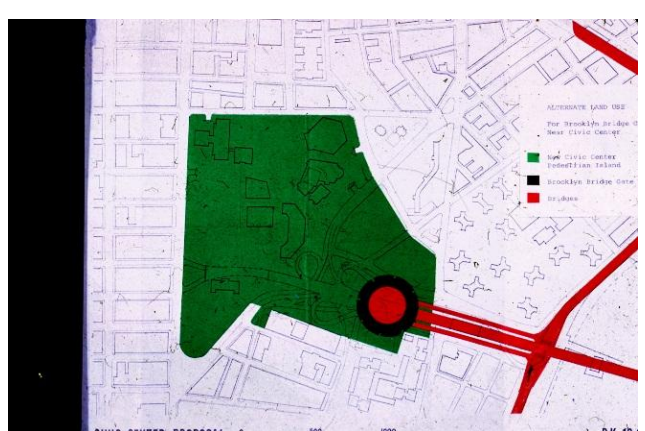

(b)

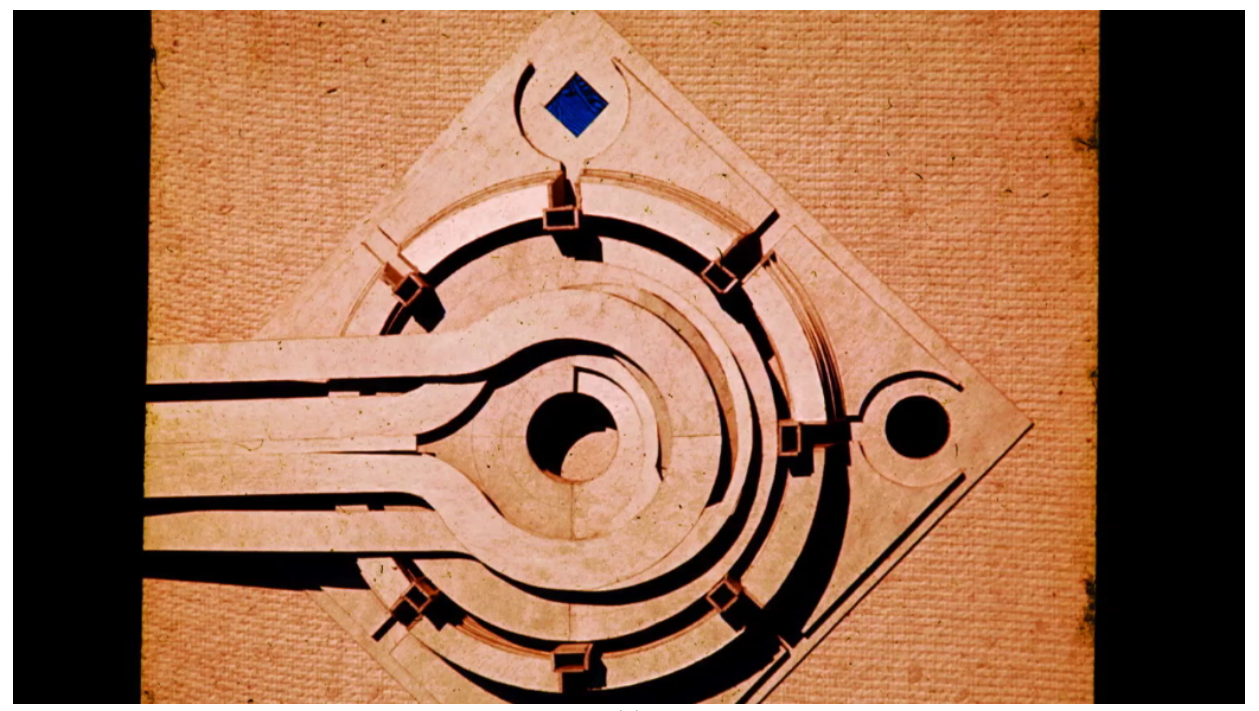

(c)

Figure 20. (a) New York City Planning, a lace of traffic roadways in red; (b) My 1969 proposal "A Gateway to Manhattan"; (c) Model of Brooklyn Bridge Gateway. 
Traffic from Brooklyn Bridge is controlled by a double helix, which stacks rather than spreads the interchange (see Figure 21). By allowing a compact interchange, this design will influence the overall solutions for the Civic Center renewal. Two-thirds of all bridge traffic is bound for destinations other than the Civic Center. This volume is rerouted directly to the East River Drive, bypassing local surface traffic in the area. The 15\% volume destined for lower Manhattan must exit to less congested local streets before reaching the East River Drive entry [16]. In addition to this interchange, the gateway structure would house: a parking garage for 1200 cars; office space and some residential space totaling 815,000 sq. ft.; and a pedestrian plaza surrounded by restaurants, conference halls and shops. Hence, by integrating many functions - transportation, work, shopping, recreation, and dwelling-into one self-contained infrastructure, valuable land in a core area is left free for human exchange. A new environment conducive to human enrichment and civic pride is created, by movement control, harnessing traffic and at the same time, releasing economic and human potential. This Brooklyn Bridge solution led to a second proposal to the Upper East Harlem Association.

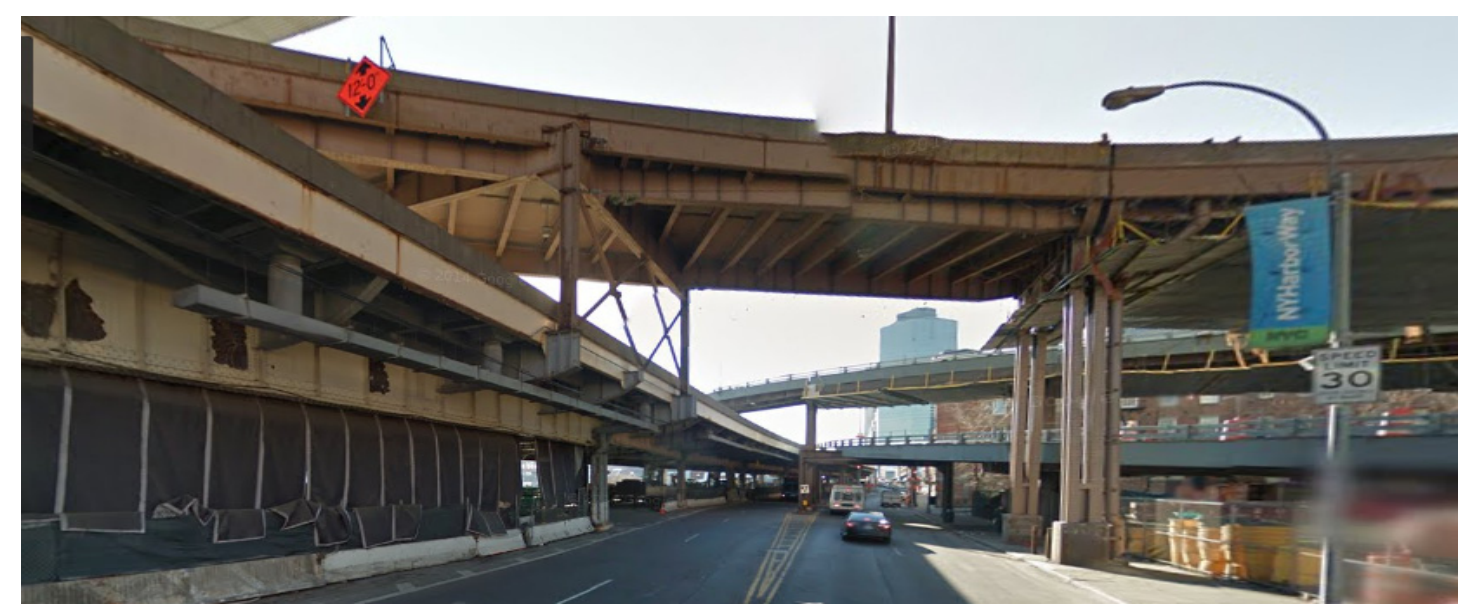

(a)

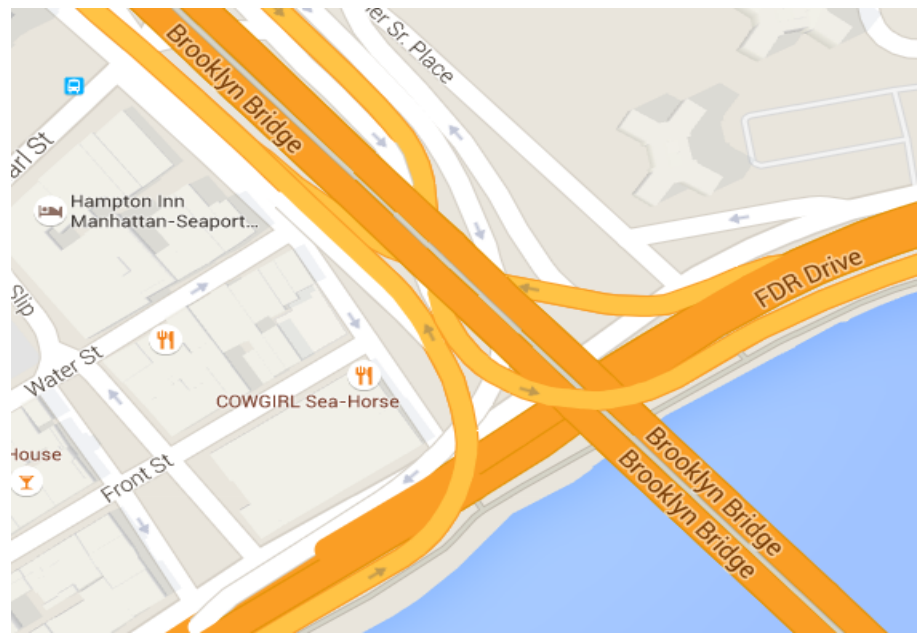

(b)

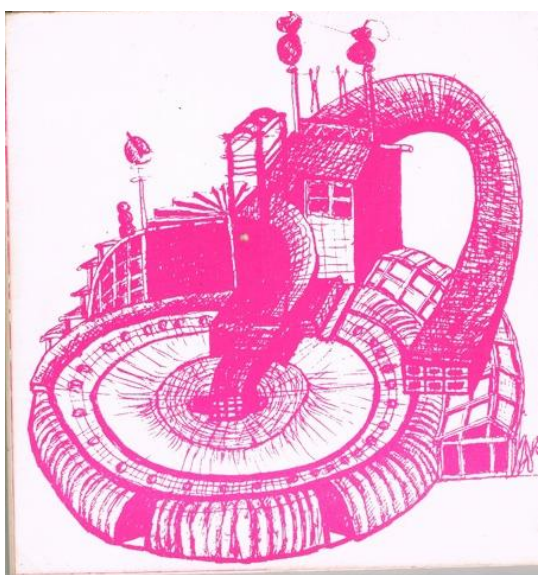

(c)

Figure 21. (a) Current Street View map of Brooklyn Bridge from Google Maps; (b) Map of Brooklyn Bridge from Google Maps; (c) Satiric drawing of gateway jungle by K Titus. Image reproduced with permission from Roger Katan.

\subsubsection{Triboro Bridge Gateways on 125th Street}

At the North end, Manhattan is connected to both the Bronx and Queens. It is known as the East Harlem Triangle (Figure 22). The Triangle community was greatly endangered by heavily used routes, 
often impossible for pedestrians to cross. This was mainly a gateway to truck traffic, thus compromising the very existence of the East Harlem community.

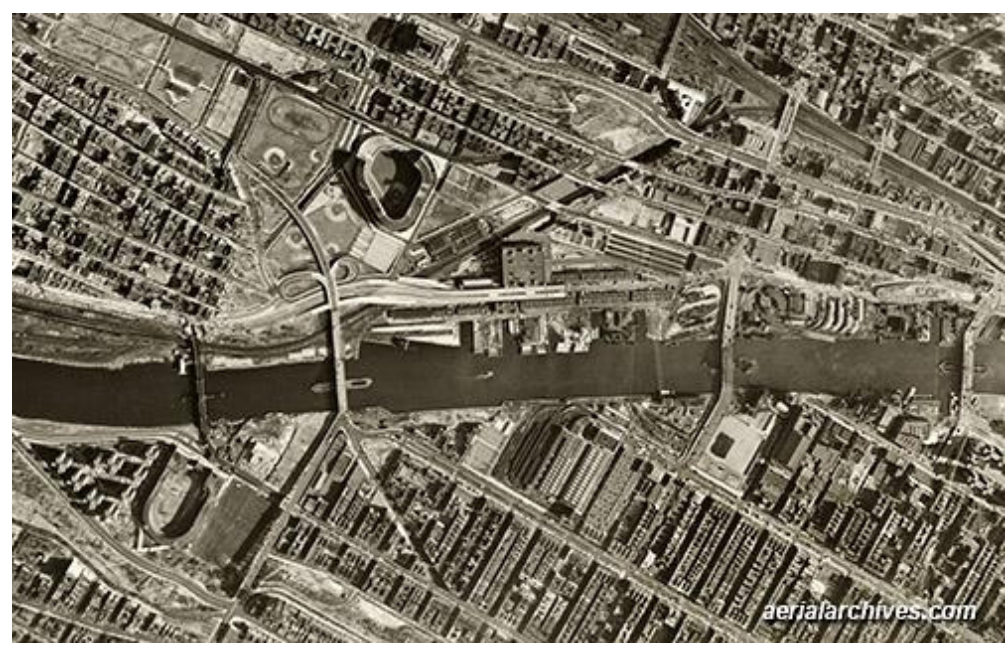

Figure 22. Aerial photos of the East Harlem Triangle with bridges over the Harlem River. Image reproduced with permission from Aerial Archives.

Traffic studies in this large area led us to a proposal of two gateways: one that would harness the traffic link to the Bronx with Third Avenue (The Northern Gateway). The other would link 125th Street with the Harlem River Drive and Triboro Bridge (The Eastern Gateway). The gateway proposal provided for systematic connections between the different modes of movement that come together in it. These connections constitute the infrastructure of the gateway (Figure 23).

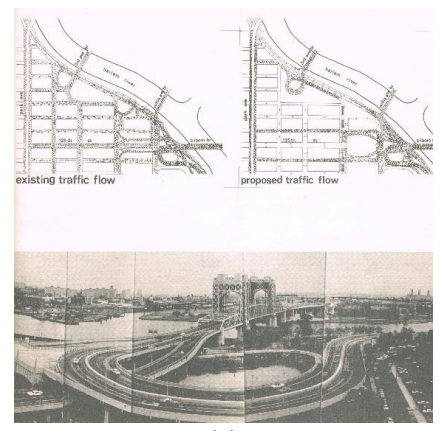

(a)

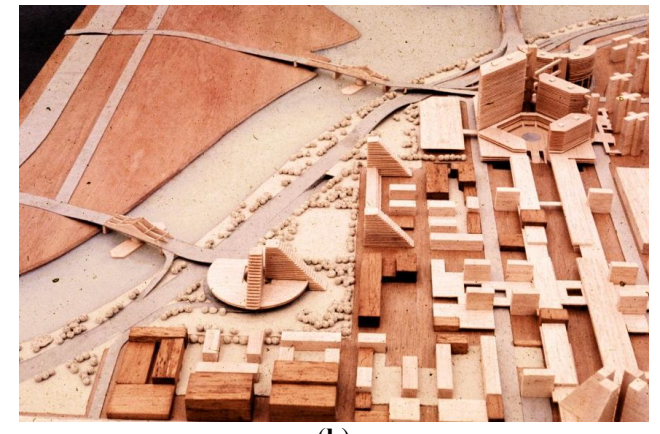

(b)

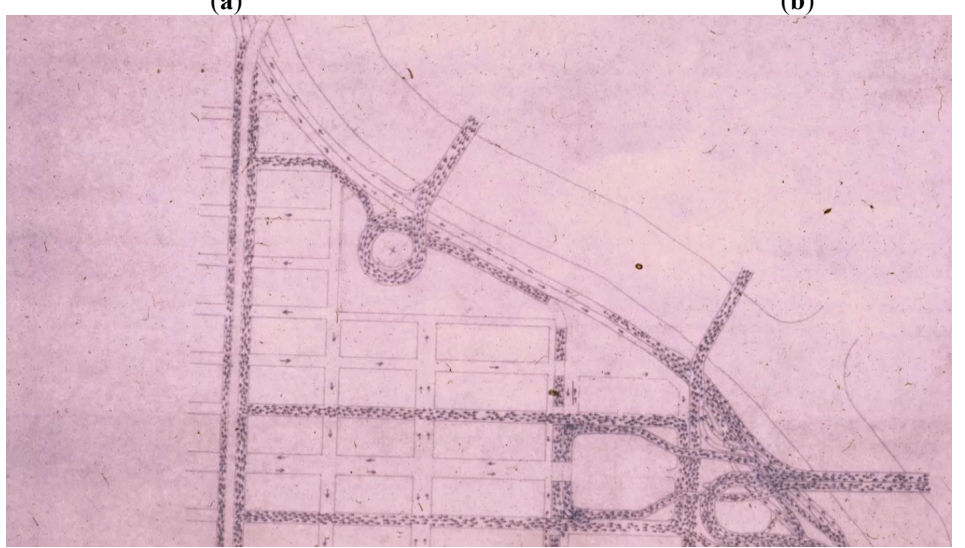

(c)

Figure 23. (a) Existing and proposed traffic flow; (b) Model of the East Harlem Northern and Eastern Gateways to New York City, 1969-1970; (c) Gateway model for rerouting 125th Street traffic. 
The Northern Gateway would liberate land for a larger park with an easier access from surrounding residential neighborhoods, and to the waterfront with a pedestrian bridge over the Harlem River Drive. The park would grow from 7 to 25 acres. These would both be gateways to Harlem and to the City.

\subsection{Times Square in East Harlem: A Kinetic Multi-Service Center}

The Multi-Service Center, part of the Community Action Agencies, created and designed in the mid-1960s by the Federal Government, was supposed to overcome the difficulties of the poor as a part of the War on Poverty (see Economic Opportunity Act) [17]. Previous public social services to help people only served to perpetuate dependency [18]. The Multi-Service Center gathered many social service programs under one roof in order to focus on each individual as a complex human being and to coordinate programs to help each person implement an individual plan. With the East Harlem leaders, we worked intensely on how to involve all residents with whatever personal or family problems they had.

Through an inviting arcade, the project was designed to attract residents from the heavily frequented street into a three story high lobby, filled with tropical island vegetation and exhibits offering information about health, social services, housing, culture and art (Figure 24a,b). Large luminous billboards similar to those in Times Square (Figure 24c) would advertise in Spanish, Italian and English, inviting people to participate in events and special programs through special announcements.
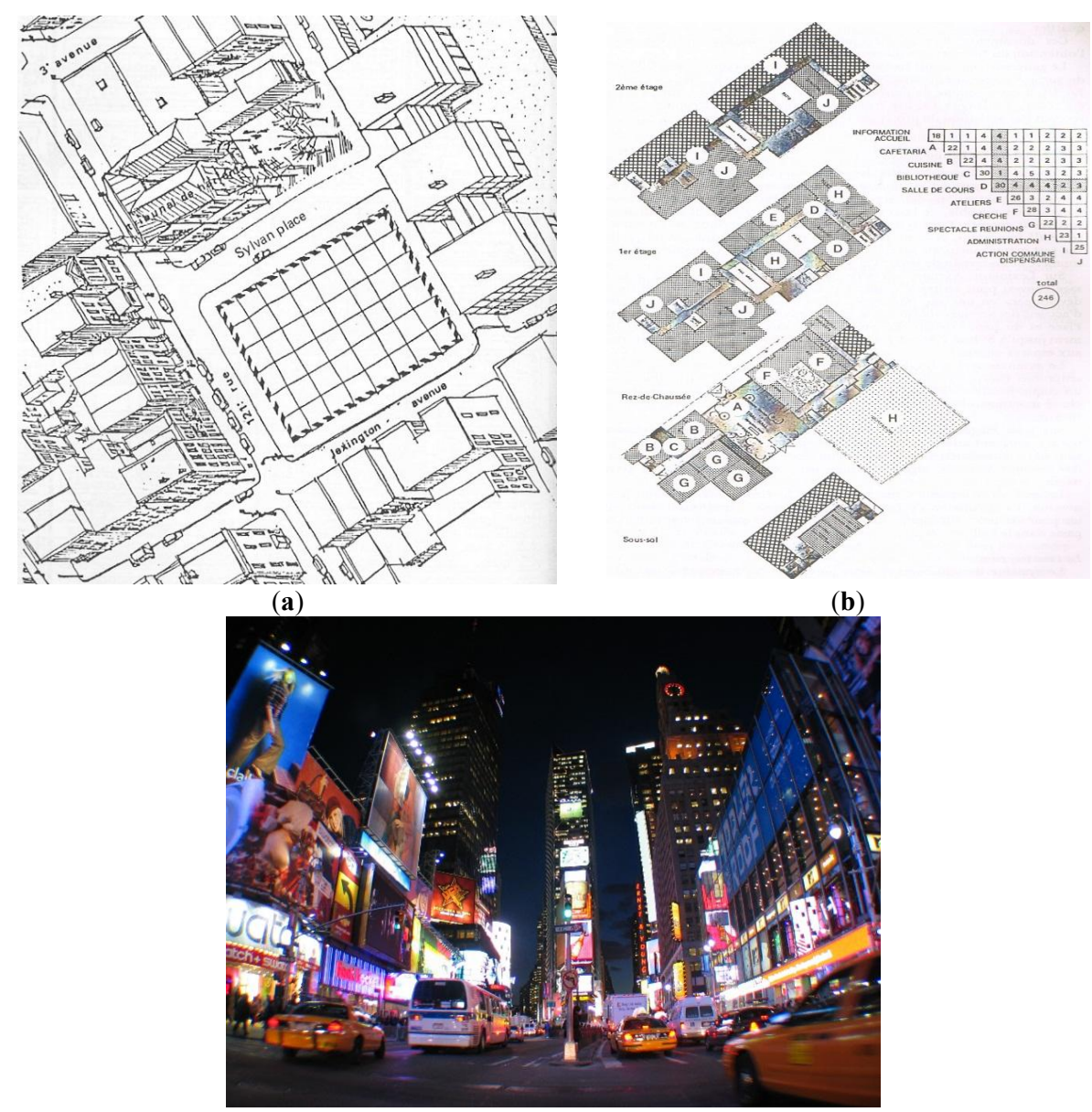

(c)

Figure 24. (a) and (b) Site plans perspective of the Multi-Service Center in East Harlem. Images reproduced with permission from Roger Katan (c) Times Square in New York City. Image courtesy of Daniel Schwen. 
After close to four years of exhilarating work with the different community groups, we finally got the approval for Federal and New York State funding. Then, without any warning, New York City was declared bankrupt, and the project was summarily dropped. I fell into a deep depression that dragged on for months. A short time later, I was frustrated to read the first publications featuring the Georges Pompidou Center in Paris (Figure 25), a building that echoed what I had tried to express in our Multi-Service Center. In Paris, the client was the French Republic President; in East Harlem, the client was the poorest of the poor. The Pompidou Center was a showcase for the highest forms of contemporary art; in East Harlem, it was the humblest of social resources for survival.

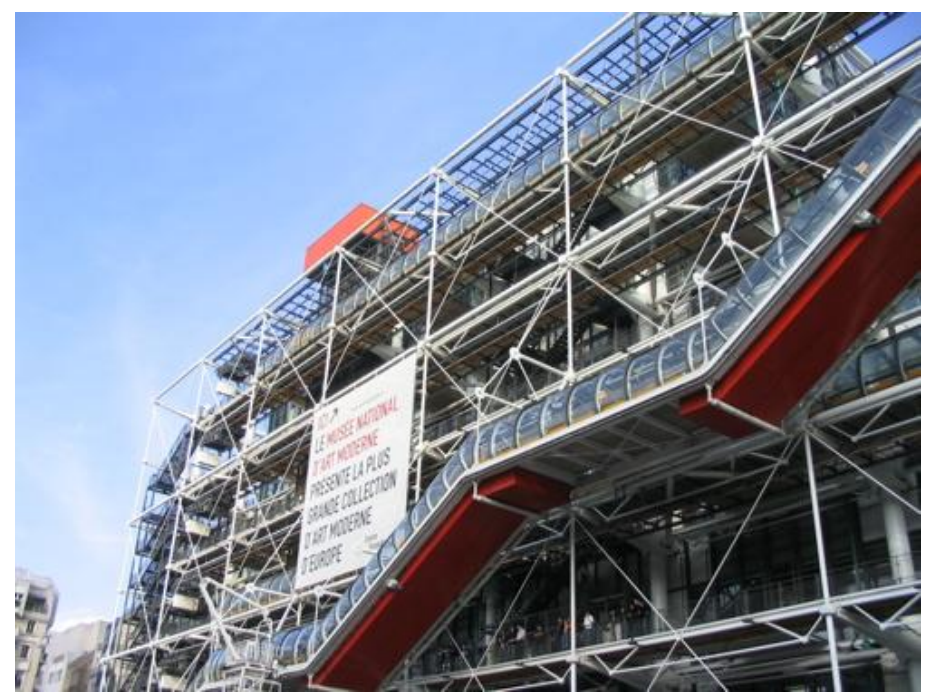

Figure 25. Georges Pompidou Center in Paris. Image courtesy of Leland.

Repeatedly, all the projects I worked on so hard for close to twelve years in East Harlem ended up as publications instead of actual building structures. I began to have a deep feeling of failure. For my mental sanity, I needed a sabbatical far away from East Harlem.

\subsection{A Period of Reflection Before the Transition}

The traditional Tuesday night gallery openings in the sixties and seventies were an attractive ritual I never escaped from. It was a refreshing time away from Harlem, when one could see friends and meet new ones, encounter art galleries and museum directors, discuss new tendencies and discover new art directions, while having good champagne with a cornucopia of delicious small goodies. It was so crowded at times that it reminded me of the weekly traditional market place of my childhood in Morocco, except that in this one no one was trading sheep. I was in Manhattan, center of the world and heart of the Arts' avant-garde.

However, returning to my home and place of work in East Harlem, after indulging in two or more gallery openings, was to come from the shiny world of opulence to the grayness of the slum. Mainly in spring and summer times, the contrast was difficult to ignore. I remember vividly coming back home one evening on a beautiful summer day with the last yellow light of a beautiful sunset walking down 116th Street sidewalk to my home. I passed by kids (two and four years old), dirty, sitting and crying in their urine on the sidewalk, at 10 p.m. with a running nose and parents on drugs not to be seen around, with nobody to put them to bed. It is particularly at those times that my artistic life brought only tension between my demanding social and community commitments and a seemingly hollow ambition.

Nineteen seventy-five was a pivotal year in choosing which direction to take. After two or three shows at the prestigious Howard Wise gallery, there was a promise to keep showing and selling my 
work in a very serious way. One of my major pieces, "Roselight for Whiteville", had a buyer at 10 times the price it had a couple years before.

By that time, almost all the new community projects we had fought for years and that I dreamed to build as a proof for a "changing" society fell through. The promised and hoped for government funds for the poor were always cut. Depression started to invade my days to the point of blocking my creativity. More and more, I questioned myself about my ability to live this life between two different worlds, parts of the same America. I could not see myself devoting fulltime to artwork, while staying around New York and turning my back to all my community friends in their hopeless fights. I felt increasingly stressed by the conflicting pressure. As new proposals came in, I decided to investigate a new direction for my life.

\section{Away from the New York Art Scene, 1976-1998}

By the end of 1975, I received two offers: one from the United Nations Development Program (UNDP) and another one from the French Ministry of Construction and Urbanism. Problems in the developing world became more important to me than the New York avant-garde. Between 1976 and 1998 I travelled from West African communities to South American cities as a consultant to international organizations, helping displaced people rediscover their traditions.

The second offer from the French Ministry of Urbanism and Construction was a grant to write about my experience with community participation and advocacy planning. The result became two "how-to" books. The first: "De Quoi Se Melent les Urbanistes?" [19], published in 1979, recounts my participatory experience, and the second, "Bâtir Ensemble" [20], published in 1988, outlines a methodology of participatory practice with case studies. By 2010, a grant from the Graham Foundation allowed me to update and expand this book. I invited Ron Shiffman to join in with two New York case studies. It has become "Building Together" published in November 2014 by the New Village Press in New York [21].

\subsection{Work in West Africa with the United Nations Development Program}

The UN's first offer was for a mission to help people in Burkina Faso, one of the world's poorest countries in West Africa. My assignment was to improve the living conditions in a large squatter settlement on the outskirts of the capital city, Ouagadougou. I helped establish a micro-saving system in 1976 that, 20 years later, has become a National Savings Federation.

In Mali in 1978, I coordinated a population transfer in the region of Selingue where a large hydroelectric dam was being built, displacing 12,000 people living in seven villages. I decided to be the first displaced, and build my house and the UN public office, right where the villages were to be rebuilt, inspired by Mali's traditional adobe architecture (Figure 26). The construction site became a two-way training program: local experts of adobe and straw-weaving taught me their traditional ways, and I taught them how to incorporate factors such as wind and shade in larger spaces in order to maintain cool air and good ventilation, as well as the use of adobe to make furniture [22]. Two years later, my model house was part of the international exhibit of adobe architecture at the Pompidou Museum in Paris in 1980.

During my first year contract with the UN, at the end of 1976, when I was working in Ouagadougou, I would head out across long desert roads in festive weekends, to visit the Malian architecture with its mosques and animist traditions, particularly the city of Djenné, as well as the Dogon country. The city of Djenné, with its Great Mosque constructed around 1280 in the time of the Mali Empire, retains its old style adobe houses in good conditions. It is a town that flourished as the trade center connecting North Africa and south Sudan [23]. Since 1988, Djenné has been registered as a UNESCO World Heritage site [23]. 


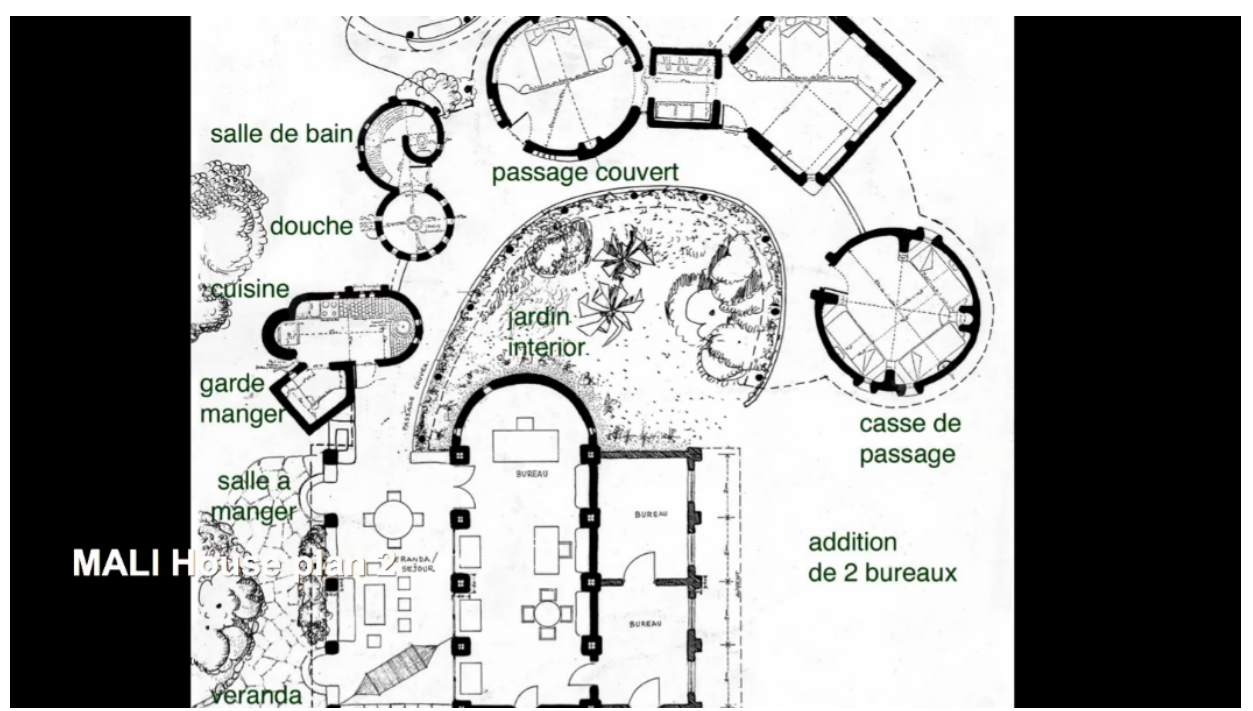

Figure 26. My model house in Mali, 1978.

The adobe village houses and mosques that I saw, which blended animist symbols with Muslim traditions, thrilled me. Animism encompasses the belief that there is no separation between the spiritual and physical (or material) world [24]. They believe that souls or spirits exist not only in humans, but also in animals, plants, rocks, geographic features, such as mountains or rivers, or other entities of the natural environment, including thunder, wind, and shadows. Today, many Malians continue to hold this belief while practicing Islam or Christianity [25]. The spontaneity of their architecture is a reflection of their ancestral animist traditions, while also intertwining their Muslim or Christian faith. Most of their houses and religious buildings have signs like decorative mounds of earth on top of their buildings: a symbol of their ancestor's spirit and a form of protection (Figure 27).

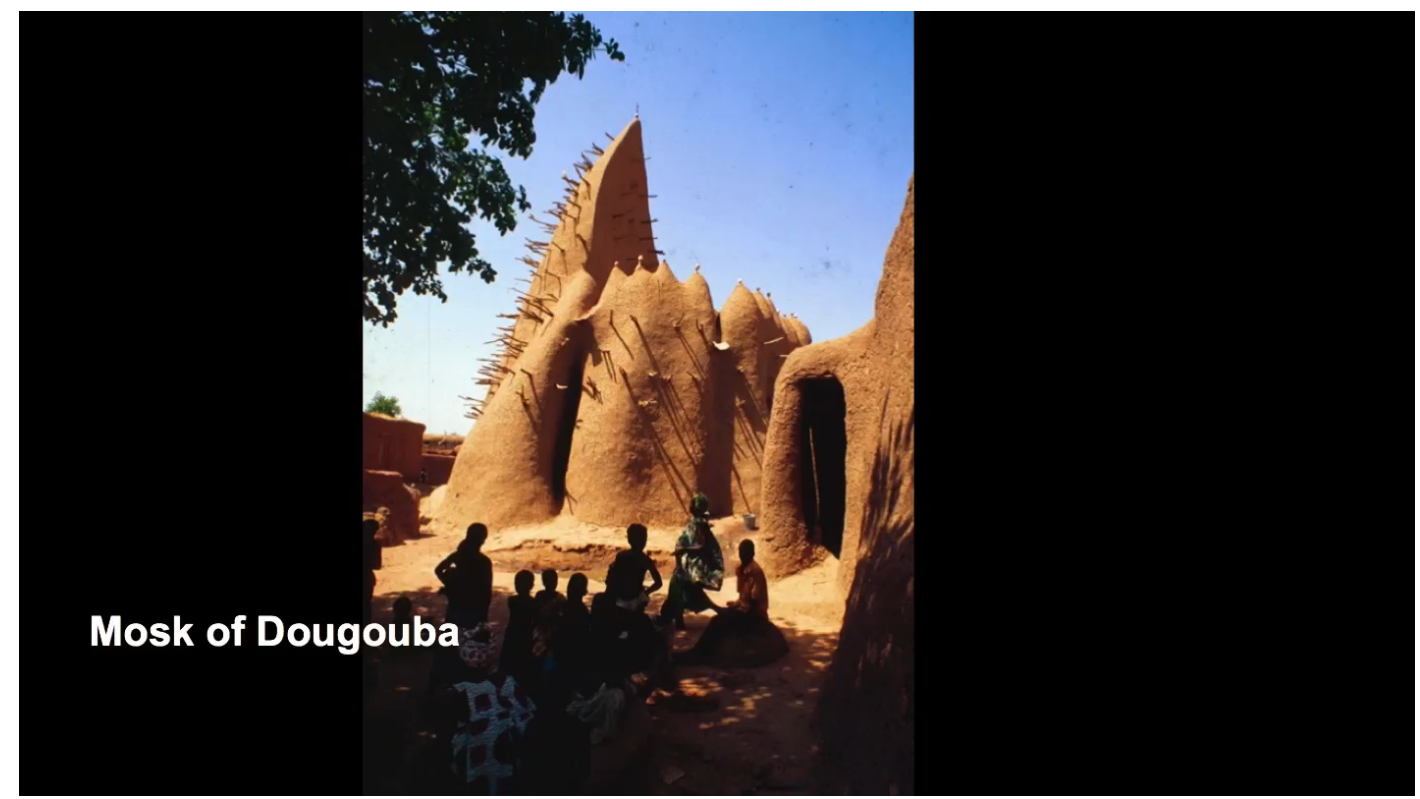

Figure 27. The famous mosque of Dougouba (a village near Mali I often visited), built like an animist shrine for their new religion. The mosques were built out of the mud that grounded them, a unique interplay between animism and Islam. 
An ephemeral material, earth is weak in rain and flood, cracks, falls down, and returns back to the ground where it came from. After the rainy season, there is something kinetic about the ritual of rehabing the walls that have melted in heavy rain. When the structure is a mosque or a community building, it becomes a village feast: women, children and men participate into the façade renewal.

Several missions from the United Nations, the French and Dutch Technical Assistance, as well as the European Union took me to Central and South America, helping displaced people by "the violencia" in Guatemala, Mexico and Nicaragua [26]. In Colombia, I coordinated a self-help housing program for the displaced in Tumaco Island, where in one night in 1983, several villages and close to 5000 houses were destroyed by a tsunami. My first mission there in 1984 was with the French Technical Cooperation to build 200 houses through self-help. In 1995 I went with the EU to build, through partial self-help, 1700 houses along with a school for 3500 children next to the 200 homes built in 1985 (Figure 28).

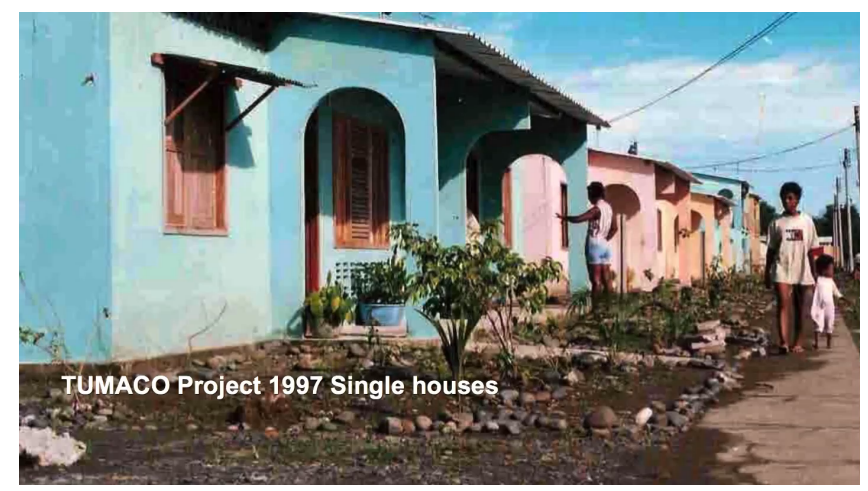

Figure 28. Tumaco Self-Help Project. Images reproduced with the permission of Roger Katan.

On the Colombian Pacific Coast, in La Bocana, a jungle in the Buenaventura estuary, I designed a self-sufficient house with a suspended pool on the third floor. Rainwater was distributed by gravity to the kitchen and two bathrooms. Electricity was supplied by two solar panels on the roof and connected to a heavy-duty truck battery, providing power for two to three hours each night. In that land, I later discovered kaolin from which I made bricks [27]. I built a kiln to fire them, and when we had enough of them, we built four bungalows, and taught the local population to build more solid homes.

\subsection{After Africa and South America}

As described earlier, when the gap between my art life and my community commitments became unbridgeable, I turned to developing country aid projects in the mid-70s. In 1999, after an active career in Africa and South America, I settled in Sauve, a medieval village in the South of France. Here I resumed my kinetic work. I got my inspiration from recent theories about the Big Bang and the early moments of the universe. The challenge was to stage such visions, which are both frightening and fascinating, and sometimes quite similar to my early childhood memories. In parallel with my writings, I have exhibited my old kinetic work and resumed my research on new kinetic expressions.

\section{Third Kinetic Period: Art that Offers the Viewer's Active Participation, 2004-2014}

After a life in orbit, while hanging African and Pre-Colombian artwork in my new house (the seventeenth) I became intrigued by one of my blinking light work I re-discovered (Figure 29). It was part of the sixties' US travelling show "A Light in Orbit". "Tide light" was made of broken white eggshells, changing hues thanks to colored Christmas bulbs blinking under a light green plexidome. Playing with those changing transparencies was a direction to investigate, in a time when LEDs were beginning to become popular. I became intrigued by the participatory possibilities it could offer when 
I discovered that multi-colored LEDs came with a remote control. I discovered in my region new industries with a wide choice of plastics and different sizes and types of clear domes. I became even more intrigued by the rejected treasures I found in their clean and large garbage bins.

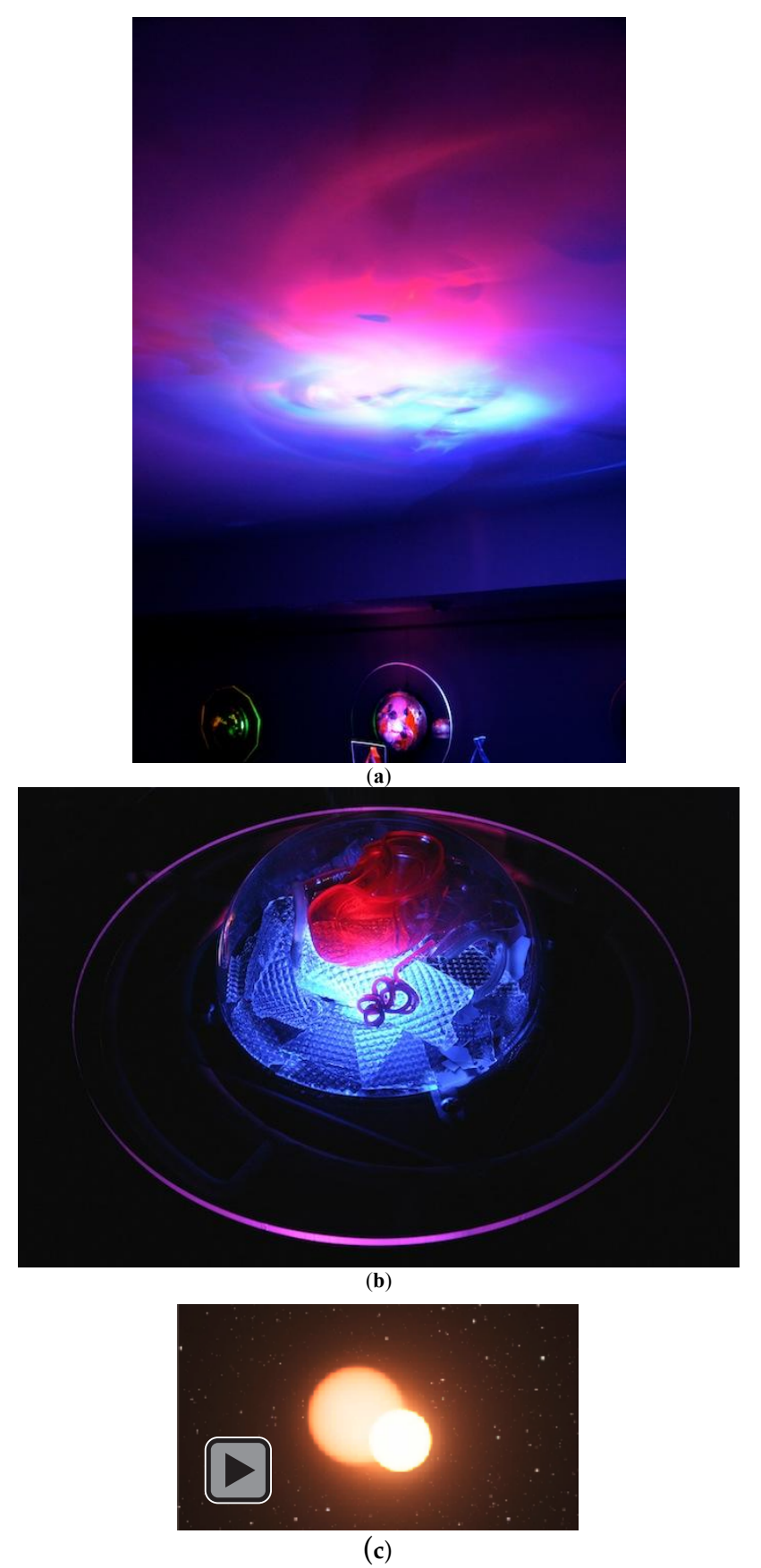

Figure 29. (a) "Tide Light" $38 \mathrm{~cm} \times 38 \mathrm{~cm} \times 15 \mathrm{~cm}$, made from eggshells, lights, and plastic (b) "The Helicoid" involves the viewer in changing colors according to one's mood. The viewer's eyes are caught by the colors of a spinning helicoid, inviting us to enter the ever-changing magnetic vortex of polar lights and their haunting mystery (c) My search for projected ever-changing lights goes into interstellar space with spheres receiving in their surface ever-changing colored forms in movement. They are like floating space capsules and can be seen in this video, "Lumières Spatiales", 2014. Images and video reproduced with permission from Roger Katan [28]. 
I became startled and inspired by scientists' articles on the elementary particles also called subatomic particles. It inspired me to imagine those very first moments at the creation of the Universe when the infinitely small collided with the infinitely big. The primordial fireball at time zero of the first moments of the universe! At time zero, why are some bosons, those elementary particles mediating fundamental interactions, such as photons, also known as light particles, massless while others are massive? What caused this phenomenon to occur? This was my inspiration.

When looking at the light works, first you enjoy a moment of peace and purity, the gentle breeze of colors and matter blowing through your mind. Then total chaos breaks out, fueled by luminous upheavals and apocalyptic visions, slowly rising and receding to finally let life emerge from the symbolic eggshells - and a new order arises. We do know that according to some mythological stories and in many ancient cultures, the birth of the Universe started with a cosmic egg, symbol of cosmogonic myth. The eggshell reaches deep into the mystery of the creation of life.

My workroom rapidly became a laboratory of accumulated objects and rejects. They were assembled, compressed, combining translucent and opaque plastics of diverse thicknesses, transformed by the heat of an oven or by a candle flame according to the product thickness. The final shape and presentation is negotiated between the position of colored LEDs, the materials' strength and the artist according to the inspiration of the moment: trying to imagine those very first instants of the Universe's creation. The changing colors of the LEDs shine through the translucent solids depending on the viewer's frame of mind-and creative remote control. These kinetic sculptures, slowly transformed by multi-color transparencies do change according to the spectator's mood. With the remote control magic, you give the spectator the feeling that he has become an actor in the arts! Matter and light are the sacred essence of all creation. The power of changing lights enhances and transforms matter. Colors and shapes merge, then alternately combine and separate, and the viewer's optic nerve finishes the rest. The shapes and colors of the solids intertwine, casting light and colors through matter. These, the founding elements of life and mankind, as imagined by the artist. The brighter the signs, the deeper they echo within ...

"Kinetic Planet Alpha", a light work piece (Figure 30), was contracted in June 2014 by the City of Sauve to be located on a pond, next to a playground, at the foot of a historical medieval wall. It landed on the pond at the foot of the high walls of Sauve, next to the playground, on 14 January 2015. Both a sculptural challenge creating optical sensations and a focal point for recreational and creative activities, Kinetic Planet Alpha is inspired by the recent discovery of the elementary particles in the primordial fireball at time zero, when the infinitely small collided with the infinitely big. Refracted on the water surface, Kinetic Planet Alpha has landed in Sauve to conjure up the very first moments of the universe. It was dedicated on 6 February 2015 in the presence of the Mayor, the Sauve Council members and with all the Sauve Association and schools representatives. On the third evening following its installation, two children, aged four and six approached the fence and the older called to his mother: "Come and see, Mom, quick! It's a real planet!"

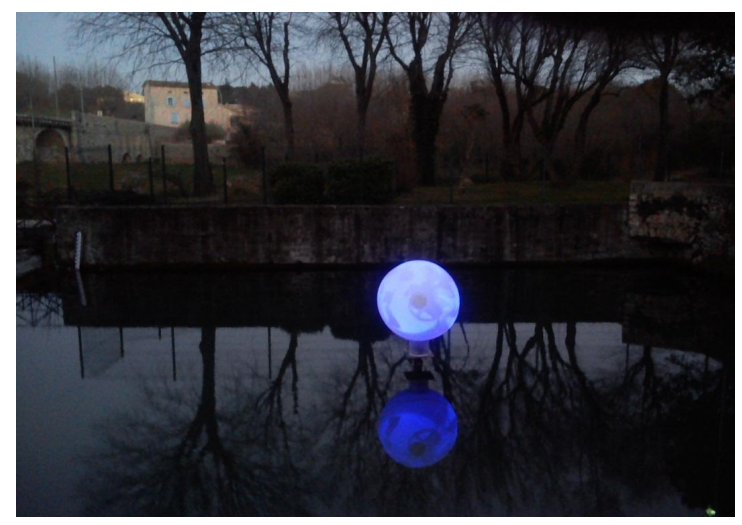

Figure 30. "Kinetic Planet Alpha" in Sauve, France, 2015. 


\section{Conclusions}

The pink and shiny suspended ever-changing bright dust of my childhood Saharan sandstorms in Southern Morocco have stuck in my mind with the same obsession Len Lye had throughout his career as a kinetic artist, when in his childhood he was fascinated with the tumbling metal noise he provoked when kicking empty tin cans in the streets. My first light boxes, like "Rose Lights for Whiteville", or the "Squares Multiples" done in the seventies were often reflections of the Moroccan village scape of my youth. In my childhood, on scorching hot days, the changes of the quality of light were striking. I often saw the horizon vibrating like a series of kinetic waves, giving close to the same lights in motion that have appeared in my last work. My childhood experiences and memories can be seen in so much of my work throughout my career, both in art and architecture. My beliefs about the importance of participatory planning and architecture are paralleled by my kinetic pieces, whether it is an early light box or a later light sculpture. All of these pieces involve the viewer participating in changing colors and rhythms, much the same way that participatory planning and architecture involves the inhabitants of a community.

Acknowledgments: The author would like to thank Serge Paul, Janice Rahn, and Chelsea Wrightson for their creative and editing contributions.

Conflicts of Interest: The author declares no conflict of interest.

\section{References and Notes}

1. Moholy-Nagy, L. "Manifesto of elemental art." In Moholy-Nagy; Edited by Passuth, K. New York: Thames and Hudson, 1985.

2. See Fondation Le Corbusier website for images of Plan Voisin. Available online: http://www.fondati onlecorbusier.fr (accessed on 8 January 2016).

3. Sartre, Jean-Paul. Existentialism Is a Humanism. Translated by Philip Mairet. Methuen: London, 1948.

4. Mumford, Lewis. The Myth of the Machine: Technics and Human Development; New York: Harcourt, Brace \& World, 1967, vol. 1.

5. Katan, R. 116th Street Renewal Plan: A Proposal for the 116th Street Renewal of the General Business, Housing, and Recreational Area, from East River Drive to 5th Avenue. New York: New York Borough Improvement Board, 1969.

6. Feidel, F., and Sidey, H. The Presidents of the United States of America, 17th ed. New York: Scala, 2006.

7. Whittemore, R. "Critical Appraisal and Exhortation-From Two Laymen." In Man, Mind, and Medicine. Paper presented at The Doctor's Education: A Chairman's View of the Swampscott Study on Behavioral Science in Medicine, Swampscott, MA, USA, 23 October-4 November 1966. Edited by Cope, Oliver. Philadelphia: J.B. Lippincott. 1968, pp. 135-38.

8. Sullivan, Louis H. “The tall office building artistically considered." Lippincott's Magazine 57 (1896): 403-9.

9. Houssay, Frédéric. Nature et Sciences Naturelles. Paris: Ernest Flammarion, 1908.

10. Moholy-Nagy, László. The New Vision, 1928: And, Abstract of an Artist, 4th ed. New York: Wittenborn Schultz, 1967.

11. Krapow, Allan. "The Legacy of Jackson Pollock." In Essays on the Blurring of Art and Life. Berkeley: University of California Press, 2003, pp. 1-9.

12. Katan, R., Krapow, A., and Smithson, R. "What is a Museum? Notes of Meeting on Museums." In Robert Smithson and Nancy Holt Papers (1907-1985). Washington: Archives of American Art, Smithsonian Institution, 19 October 1966. typescript on microfilm, reel 3834, frames 1081-86.

13. Lye, L. The Art That Moves. Unpublished. 17 October 1965.

14. Margolies, J. Architecture and the kinetic movement: The work of Roger Katan. Art Voices 5 (1966): 74-81.

15. Wallace, D., McHarg, I., Roberts, W., and Todd, T. Lower Manhattan Plan; Capital Project ES-1. New York: New York City Planning Commission, 1966.

16. Numbers came from a report from traffic engineers working with Roger Katan on the project.

17. United States Federal Government. Economic Opportunity Act of 1964; Public Law 88-452. Washington: United States Government Printing Office, 1964. 
18. "Welfare." In West's Encyclopedia of American Law. Available online: http:/ /www.encyclopedia.com/topic/ Welfare.aspx (accessed on 8 January 2016).

19. Katan, R. De Quoi Se Melent les Urbanistes?. Paris: Actes Sud, 1979.

20. Katan, R. Bâtir Ensemble. Paris: CILF, 1988.

21. Katan, Roger, and Ronald Shiffman. Building Together: Case Studies in Participatory Planning and Community Building. New York: New Village Press, 2014.

22. Images. Available online: http:/ /www.rogerkatan.wordpress.com (accessed on 8 January 2016).

23. Old Towns of Djenné. Available online: http://whc.unesco.org/en/list/116 (accessed on 8 January 2016).

24. Park, G. K. Animism. Encyclopaedia Britannica. Available online: http://www.britannica.com/topic/animism (accessed on 8 January 2016).

25. Central Intelligence Agency. The World Factbook: Religions. Available online: https://www.cia.gov/library/ publications/the-world-factbook/fields/2122.html (accessed on 8 January 2016).

26. La Violencia. Available online: http://www.globalsecurity.org/military/world/war/la-violencia.htm (accessed on 8 January 2016).

27. Kaolin. In Encyclopaedia Britannica. Available online: http://www.britannica.com/science/kaolin (accessed on 8 January 2016).

28. For more videos of my kinetic work. Available online: http://www.rogerkatan.format.com.

(C) 2016 by the author; licensee MDPI, Basel, Switzerland. This article is an open access article distributed under the terms and conditions of the Creative Commons by Attribution (CC-BY) license (http:/ / creativecommons.org/licenses/by/4.0/). 